Issued by Sandin National Laboratories, operated for the United States Department of Fnergy by Sandia Corporation.

NOTICE. This report was prepared as an account of work eponsored by an agency of the United States Government. Neither the United States Government nor any agency thereof, nor eny of their employees, nor any of their contractors, eubcontractors, or their employees, makes any warranty, express or implied, or assumes any legal liability or responsibility for the accuracy, completeness, or usefulness of any information, apparatus, product, or process disclosed, or represents that its use would not infringe privately owned rights. Reference herein to eny specific commercial product, process, or service by trade name, trademart, manufacturer, or otherwise, does not necessarily constiturte or imply its endorsement, recommendation, or favoring by the United 8tates Government, eny agency thereof or any of their contractors or aubcontractors. The views and opinions expressed herein do not necessarily state or reflect those of the United States Government, any agency thereof or any of their contractors or nubcontractors.

Printed in the United States of America Available from

National Technical Information Service

U.S. Department of Commerce

6285 Port Royal Road

Springfield, VA 22161

NTIS price codes

Printed copy: A03

Microfiche copy. A01 


\section{DISCLAIMER}

This report was prepared as an account of work sponsored by an agency of the United States Government. Neither the United States Government nor any agency Thereof, nor any of their employees, makes any warranty, express or implied, or assumes any legal liability or responsibility for the accuracy, completeness, or usefulness of any information, apparatus, product, or process disclosed, or represents that its use would not infringe privately owned rights. Reference herein to any specific commercial product, process, or service by trade name, trademark, manufacturer, or otherwise does not necessarily constitute or imply its endorsement, recommendation, or favoring by the United States Government or any agency thereof. The views and opinions of authors expressed herein do not necessarily state or reflect those of the United States Government or any agency thereof. 


\section{DISCLAIMER}

Portions of this document may be illegible in electronic image products. Images are produced from the best available original document. 


\title{
STATIC SLOT TESTING OF CONVENTIONAL LOST CIRCULATION MATERIALS
}

Thomas E. Hinkebein, Enhanced Oil Recovery Division, 9755

Vance L. Behr,

Nuclear Systems Technology Division, 9411

Steve L. Wilde,

EGEG, Inc.

\begin{abstract}
A study of the utility of conventional lost circulation materials and testing methods was performed using a modified API slot tester. Five lost circulation materials were evaluated in 266 tests at both room temperature and temperature-aged conditions simulating expected geothermal environments. A large variation in the maximum pressure (or sealing pressure) the plug could withstand was attributed to nonrepeatability in plug strengths. Plugs were composed of multiple or single particle bridges, with the latter providing stronger, better sealing plugs. Seals occurred on the upstream surface of the slots in a11 cases. Sealing pressures generally decreased with increasing slot widths and decreasing solids concentration. When the slot width was". less than the size of the largest rigid particle in the lost circulation slurry, sealing pressure was maximized. When the slot width was greater than three times the maximum rigid particle size, no significant sealing ability was observed with the conventional materials tested. Addition ally, cellulosic lost circulation materials are severely degraded by temperature aging. Mud gellation provided no significant improvement in lost circulation material sealing ability.
\end{abstract}



CONTENTS

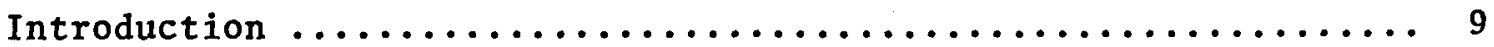

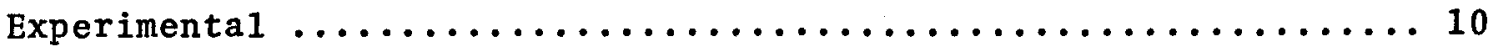

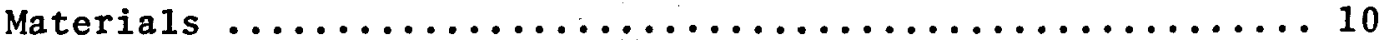

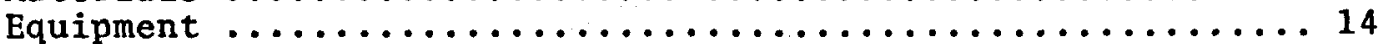

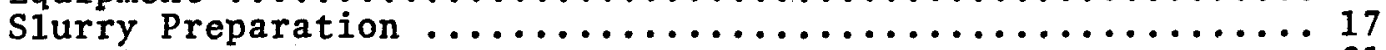

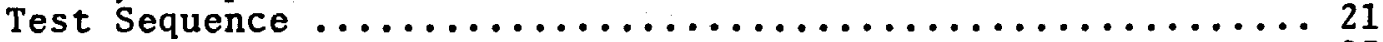

Results ..................................... 23

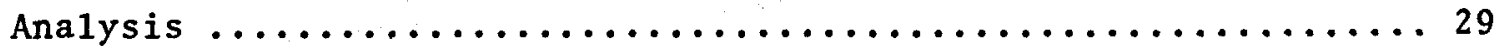

ANOVA on Mixing and Sorting Data ................ 31

Comparisons of Maximum Sealing Pressure

with Standard API Slots and 6 In Long Slots .......... 32

Comparison of Tapered Slot Sealing Data to

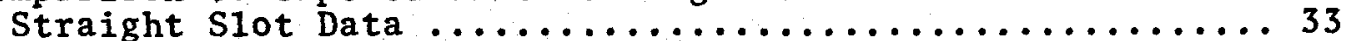

Effect of LCM Concentration on Sealing Ability .......... 34

Effect of Slot Size on Sealing Ability ................... 34

Effect of Temperature on Lost Circulation Material (LCM) ... 35

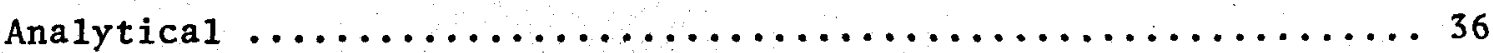

Comparison Between Lost Circulation Bridging

Material Plug Formation Mechanics and

Permeability Impairment Mechanics ............... 36

Single Particle Bridge Strength .................. 37

Multi-Particle Bridge Strength .................... 39

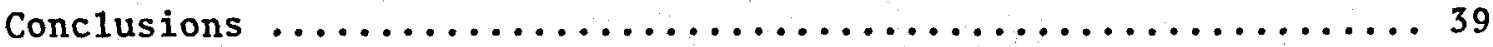

Recommendations ........................... 40

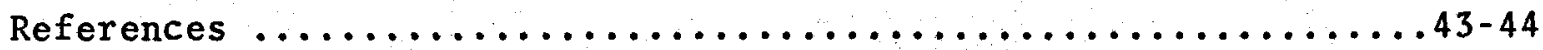

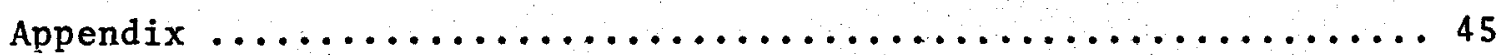

Analysis of Variance (ANOVA) $\ldots \ldots \ldots \ldots \ldots \ldots \ldots \ldots \ldots \ldots \ldots$ 



\section{FIGURES}

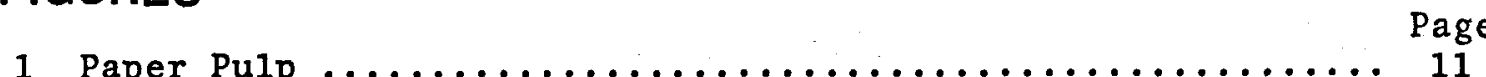

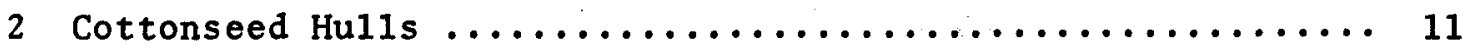

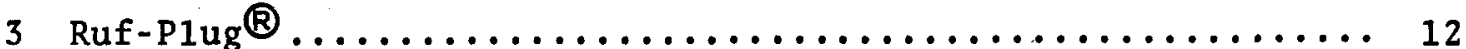

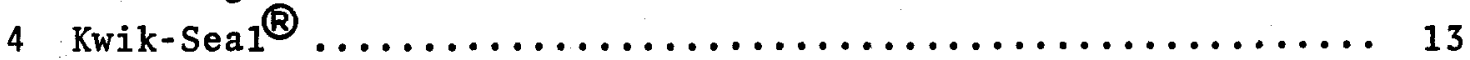

5 Ground Battery Casings ...................... 14

6 Modified API Lost Circulation Test Cel1 .............. 15

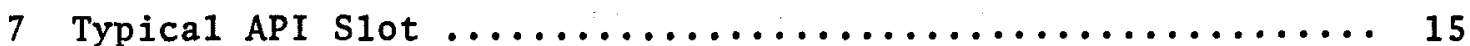

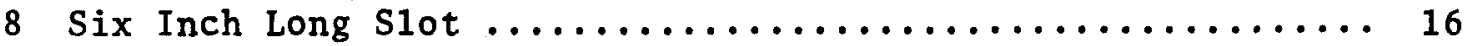

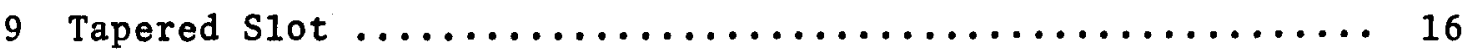

10 Couette Mixer Composed of a Right Circular

Cylinder Fitted to a Standard Laboratory Mixer ......... 19

11 Face Seal of Kwik-Seal at 5 ppb on a 0.04 in

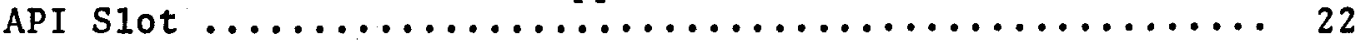

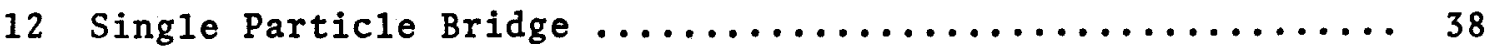

\section{TABLES}

1 Tapered slots $\ldots \ldots \ldots \ldots \ldots \ldots \ldots \ldots \ldots \ldots \ldots \ldots \ldots \ldots \ldots \ldots \ldots$

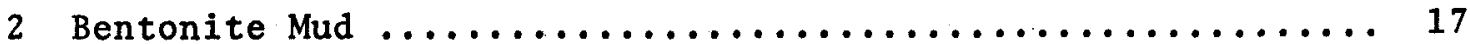

3 Paper Pulp-Lost Circulation Tests .................. 23

4 Cottonseed Hu11s-Lost Circulation Tests Concentration of Cottonseed Hulls-5 1b/bb1 ............ 23

5 Cottonseed Hulls-Lost Circulation Tests Concentration of Cottonseed Hul1s-10 1b/bb1 ........... 24

6 Kwik-Sea1-Lost Circulation Tests Concentration of Kwik-Sea1-5 1b/bb1 ................ 24

7 Kwik-Sea1-Lost Circulation Tests Concentration of Kwik-Sea1-10 1b/bb1 .............. 25

8 Ruf-Plug-Lost Circulation Tests Concentration of Ruf-P1ug-10 $1 \mathrm{~b} / \mathrm{bb} 1 \ldots \ldots \ldots \ldots \ldots \ldots$

9 Ruf-Plug-Lost Circulation Tests Concentration of Ruf-P1ug-30 1b/bb1 ............... 26

10 Ruf-Plug-Lost Circulation Tests Concentration of Ruf-Plug-60 1b/bb1 ................ 26

11 Ground Battery Casings-Lost Circulation Tests .......... 27

12 Tapered Slot-Lost Circulation Tests ................ 28 


\section{TABLES CONT,}

13 Temperature Aged-Lost Circulation Tests ............. 28

14 Effect of Mixing on Maximum Sealing Pressure

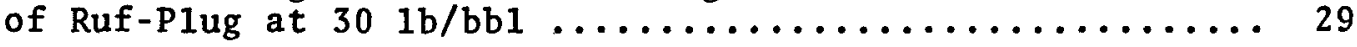

15 Effect of Particle Sorting on Maximum Sealing

Pressure of Ruf-Plug at $301 \mathrm{~b} / \mathrm{bb} 1$ in 0.12 in $\mathrm{S} 1$ ot ...... 30

16 Comparison of Maximum Sealing Pressure Obtained with API Slots and 6 in Long Slots ................ 32

17 Comparison of Number of Runs Where Sealing at 1000 psi Occurred to Total Number of Runs .......... 35 


\section{INTRODUCTION}

Lost circulation is an interruption in the circulation of drilling fluid caused by fluid entering into either a porous or fractured formation underground rather than returning to the surface. Lost circulation is a significant field problem. ${ }^{1}$ It is worse in zones having natural fractures or vugular regions which occur more frequently in geothermal areas, and its occurrence leads to problems including borehole instability, stuck pipe, and improper casing cementing. Operators prefer to solve lost circulation problems by using lost circulation materials (LCM) which may be kept available at the drilling site. These materials are added directly to the drilling fluid and are circulated to the formation where loss of fluid occurs. At this location, they tend to form a physical plug which arrests the fluid loss. Hence, LCM provide the first line of defense against lost circulation. As such, a need exists to define more representative testing methods for LCM and the static slot testing of several commercially available materials is viewed as the first step in a program continuing at Sandia National Laboratories to provide for testing and development of lost circulation materials.

The use of the API slot tester as a device for testing lost circulation materials is well documented. ${ }^{2}$. The procedures for its use were previously given in American Petroleum Institute Recommended Practice $13 \mathrm{~B} .{ }^{3}$ Though references to slot testing were removed from $\mathrm{RP}$ 13B in 1982, the procedures and apparatus described there are referred to here as the API tester. The static slot testing of a lost circulation material allows the determination of the maximum pressure which a LCM plug will seal across a predetermined slot size. This maximum sealing pressure provides a measure of the value of the LCM for actual field 
operation and is the primary quantity measured in these tests.

Since the maximum sealing pressures are observed to be highly variable, it is desirable to view these pressures relative to the pressures which will actually occur in the wellbore. The wellbore pressure will have several components associated with it. The difference between the hydrostatic fluid head of the drilling fluid and the formation pore pressure is more than $500 \mathrm{psi}$ for many geothermal formations which are typically underpressured. The dynamic pressure associated with the fluid surge when the drill pipe is run into the hole is also of the order of $500 \mathrm{psi}^{4}$ so that downhole pressures that are $1000 \mathrm{psi}$ greater than the formation pressure are not uncommon. Hence, for a lost circulation material to be useful in geothermal formations, it must be capable of sealing $1000 \mathrm{psi}$ in the modified API tester.

\section{EXPERIMENTAL}

\section{A. Materials}

Four materials were initially selected for testing. These were paper pulp, cottonseed hulls, Kwik Seal ${ }^{\circledR}$, and Ruf-Plug ${ }^{\circledR}$. A fifth material, ground battery casings, was added later in the program. Historically, lost circulation material selection has been based on what was economically available and in quantity near the drill site. This explains the application of such common materials as cottonseed hulls and paper pulp.

Paper pulp is a very fine fibrous material as shown in Figure 1. There are no rigid particles in this material and it performed very poorly in the initial tests, failing to seal even a .04 inch crack. For this reason, paper pulp was dropped from the test matrix early in the program. However, cottonseed hulls, in addition to having a moderate amount of cotton fibers, are composed primarily of the hulls themselves as seen in Figure 2. The hulls are rigid, serve to bridge a crack, and provide structural support. The fibers tend to act as 


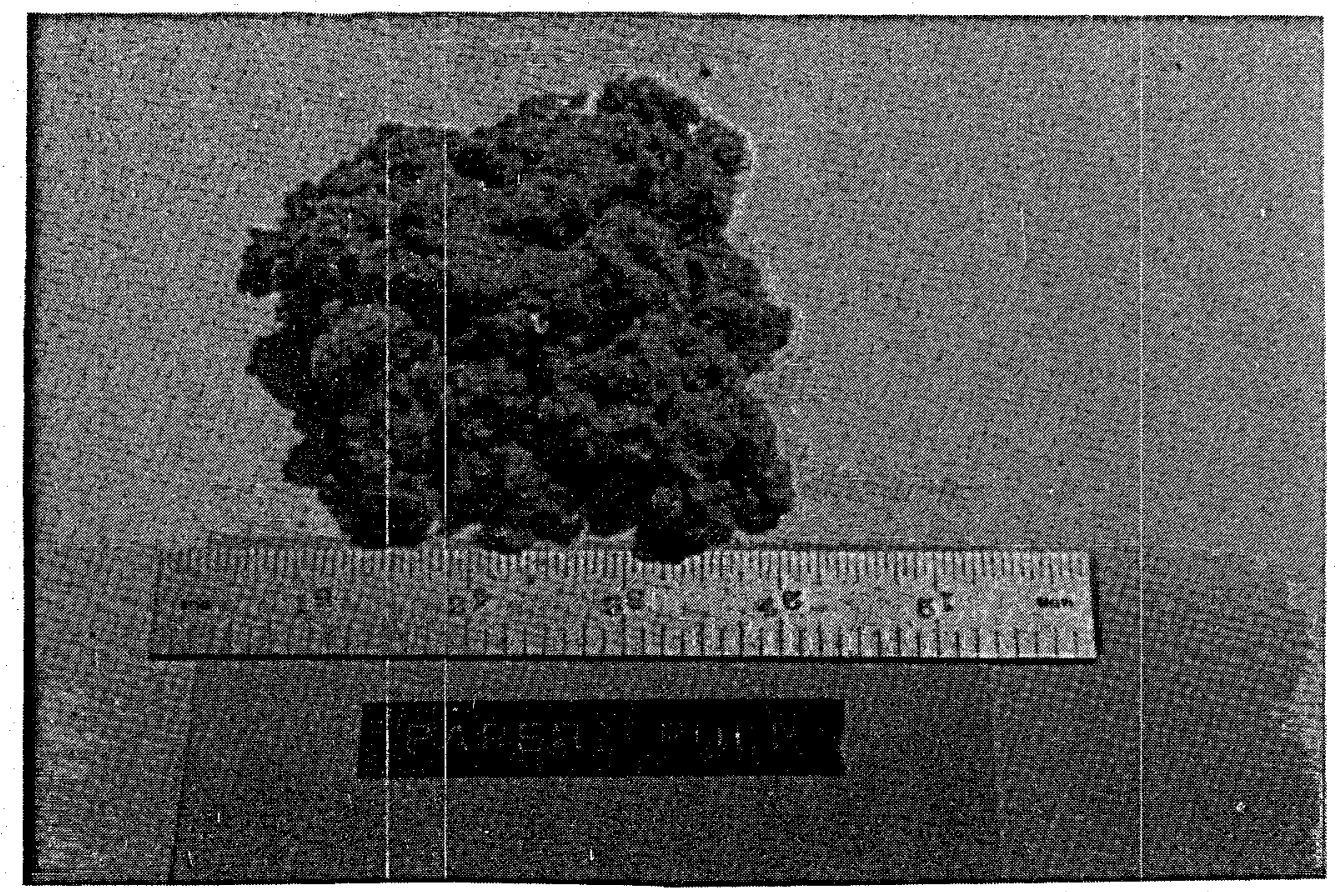

Figure 1. Paper Pulp

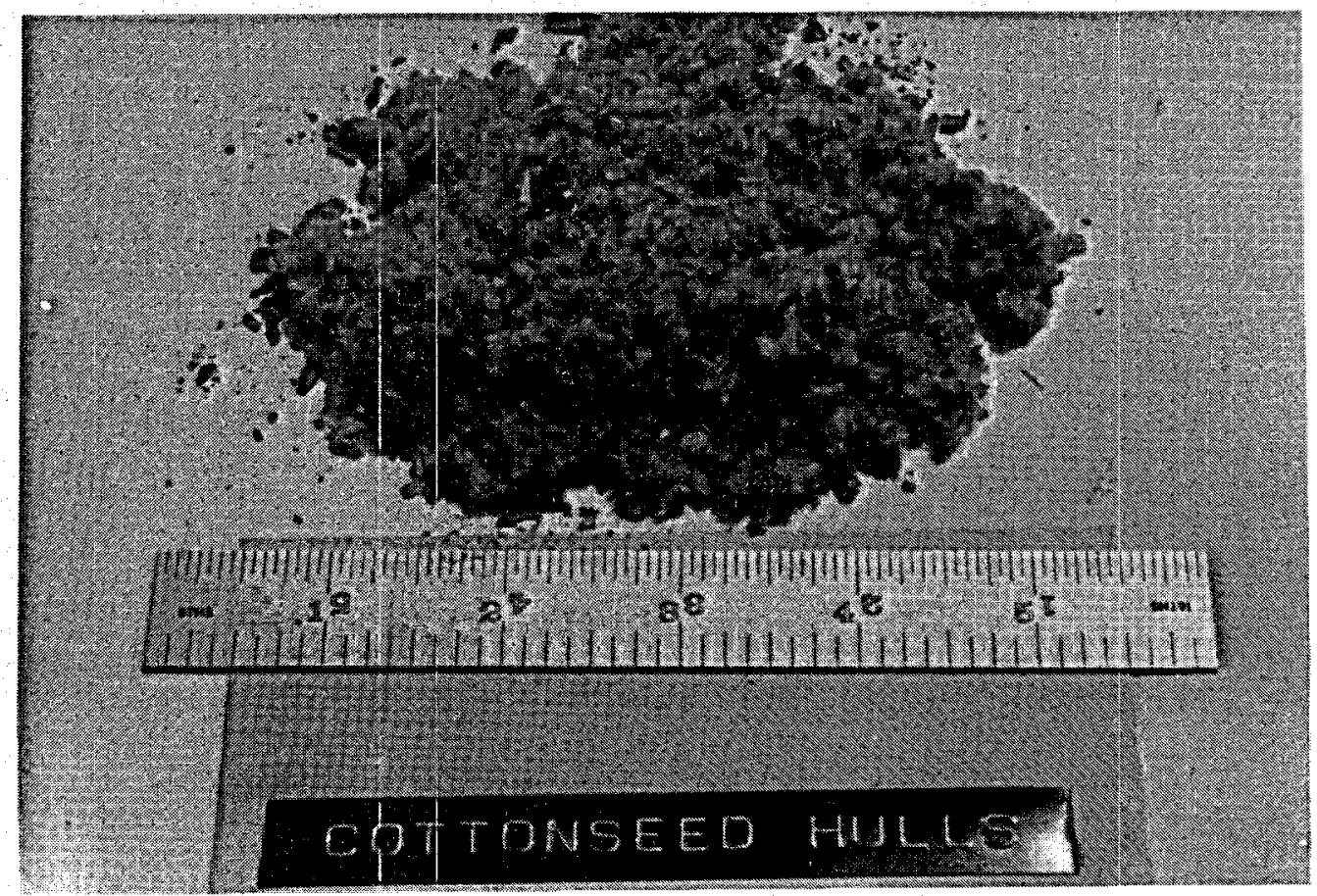

Figure 2. Cottonseed Hulls 
gaskets between successive layers of hulls. Ruf-Plug ${ }^{\mathbb{B}}$ is a trade name for ground corn cobs and is another material used because of economic and availability considerations. This material is granular as seen in Figure 3 and performs well sealing cracks smaller than or near the same size as the granule size.

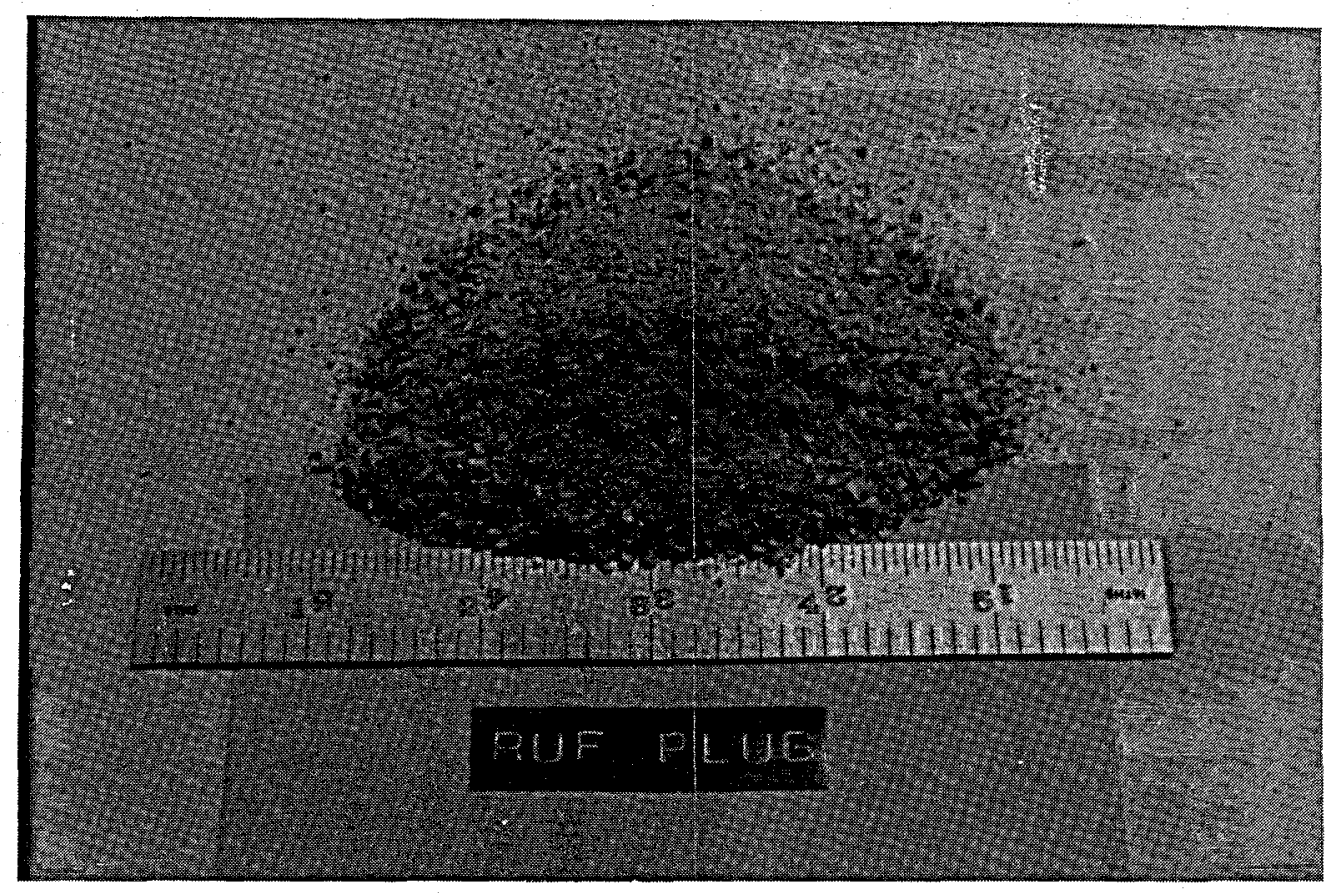

Figure 3. Ruf-Plug

As the knowledge of the industry progressed it was recognized that a LCM, which could be applied for a wide range of problems, was needed. Kwik Seal ${ }^{(R)}$ arose as one of these products and consists of fibers, flakes, and granules as seen in Figure 4. The different component materials act synergistically to form a strong, low permeability seal. 


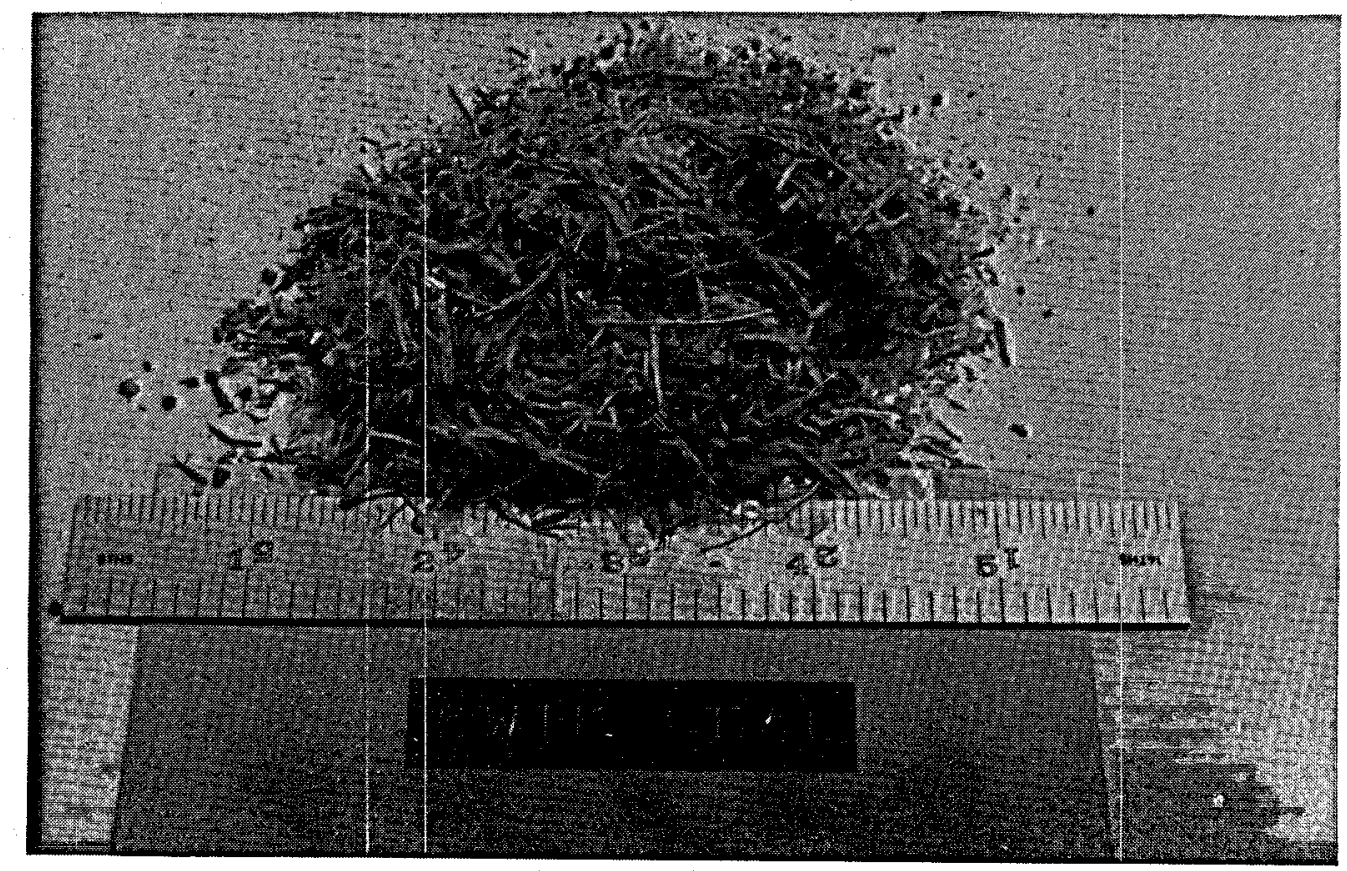

Figure 4. Kwik-Seal

For geothermal applications any successful LCM must be able to perform at elevated temperatures. All of the materials discussed above degrade at high temperatures. Because of this limitation, one more material was added to the program which was claimed by the supplier to be stable at temperatures in excess of $600^{\circ} \mathrm{F}$. This material is composed of granules of various resin as shown in Figure 5 , and is produced by grinding up reclaimed battery casings. While this material is not a conventional LCM, it is a commercially available product and is not a thermally sensitive cellulosic material and hence is a good candidate for use at high temperature. 


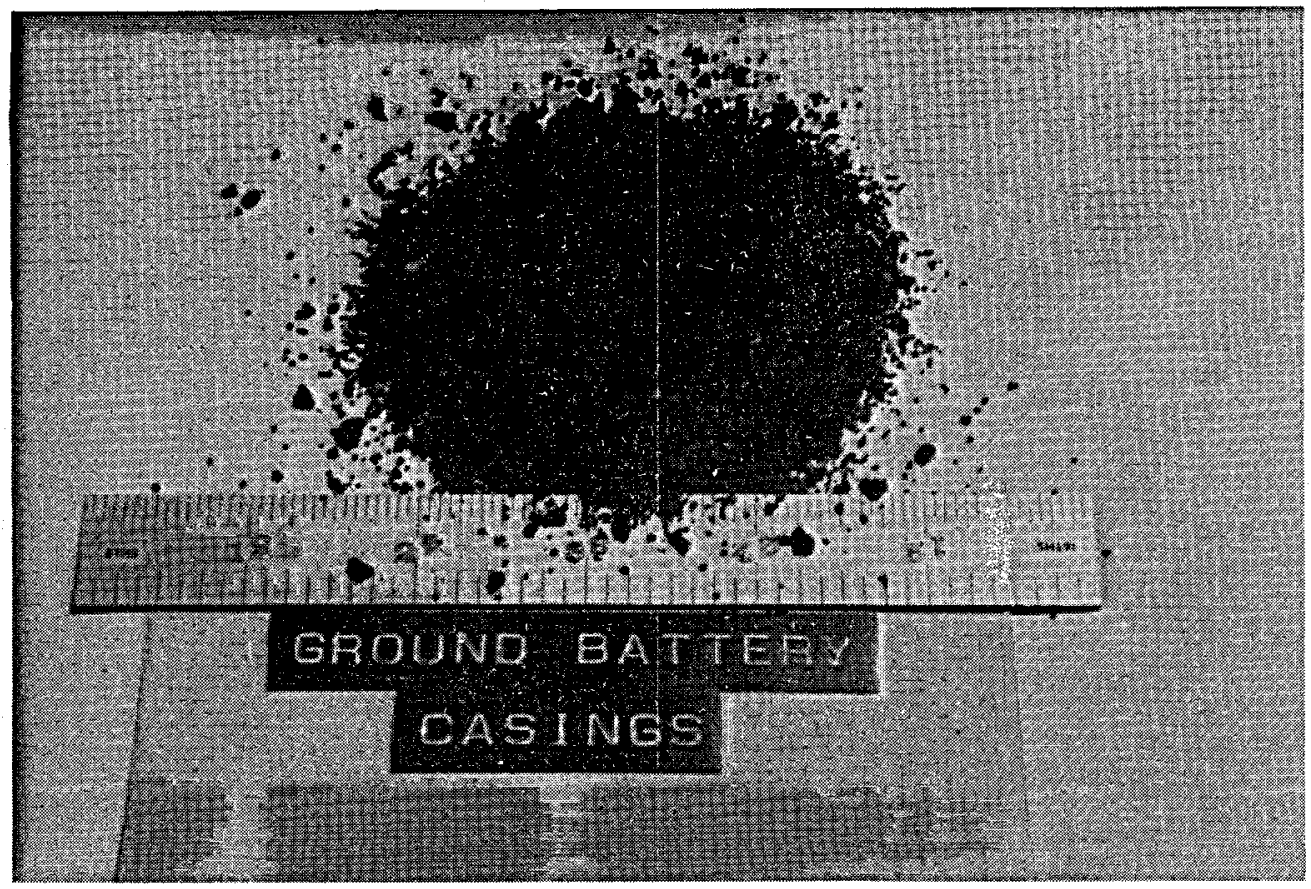

Figure 5. Ground Battery Casings

\section{B. Equipment}

A modified API lost circulation test cell used in conducting these tests is shown in Figure 6. It consists of a reservoir for holding a drilling mud--LCM slurry with either balls (simulating porous media flow) or slots (simulating fractures) used at the exit of the reservoir. On1y slots were examined during the course of these experiments.

The standard API slots tested during experimentation had openings of $0.04 \mathrm{in}, 0.06 \mathrm{in}, 0.08 \mathrm{in,} 0.12 \mathrm{in,} 0.16 \mathrm{in}$, and $0.20 \mathrm{in.} \mathrm{A} \mathrm{typica1}$ API slot is shown in Figure 7. Additionally, several 6 in long slots were fabricated and the standard cell modified such that these slots could be used in place of the standard API slots. These long slots had openings of $0.08 \mathrm{in}, 0.12 \mathrm{in,} 0.16 \mathrm{in}, 0.20 \mathrm{in}$, and $0.25 \mathrm{in}$. As shown in Figure 8 , the long slots may be disassembled for cleaning, and each half of the long slot may be interchangeably fitted with any other so that seven other slot widths are possible, $0.10 \mathrm{in}, 0.14 \mathrm{in}, 0.165$ in, $0.18 \mathrm{in,} 0.185 \mathrm{in}, 0.205 \mathrm{in}$, and $0.225 \mathrm{in}$. 


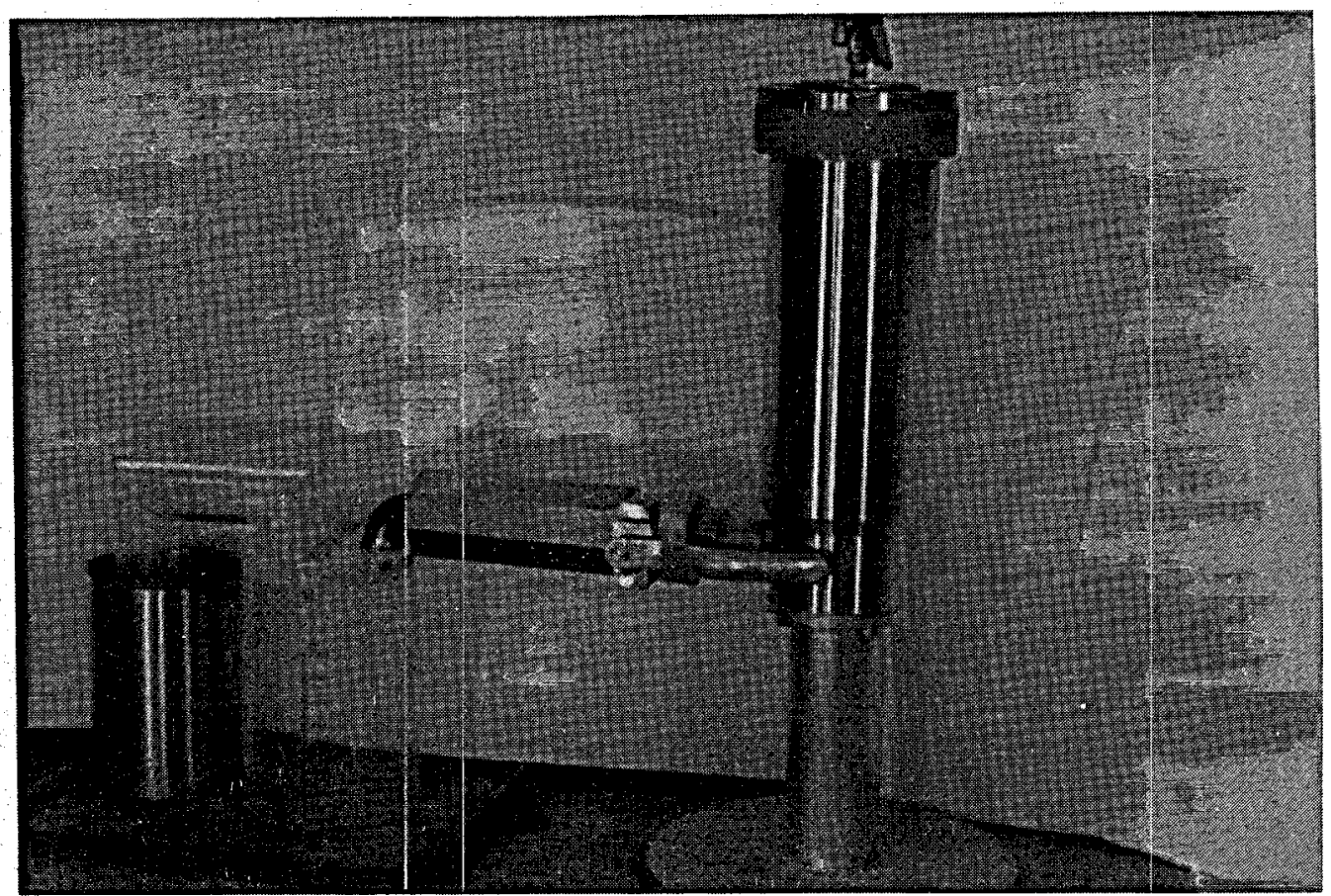

Figure 6. Modified API Lost Circulation Test Cell

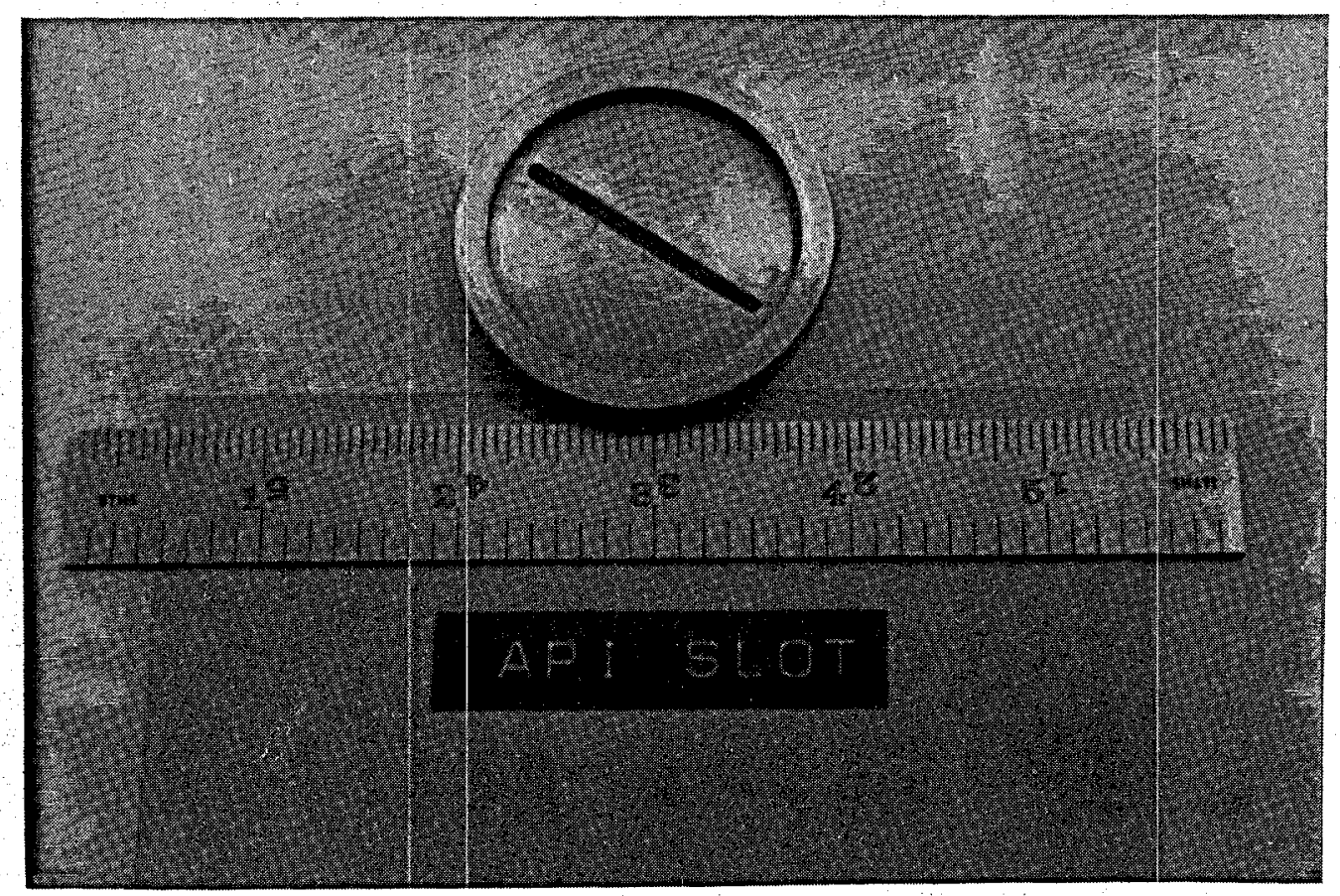

Figure 7. Typical API S1ot 


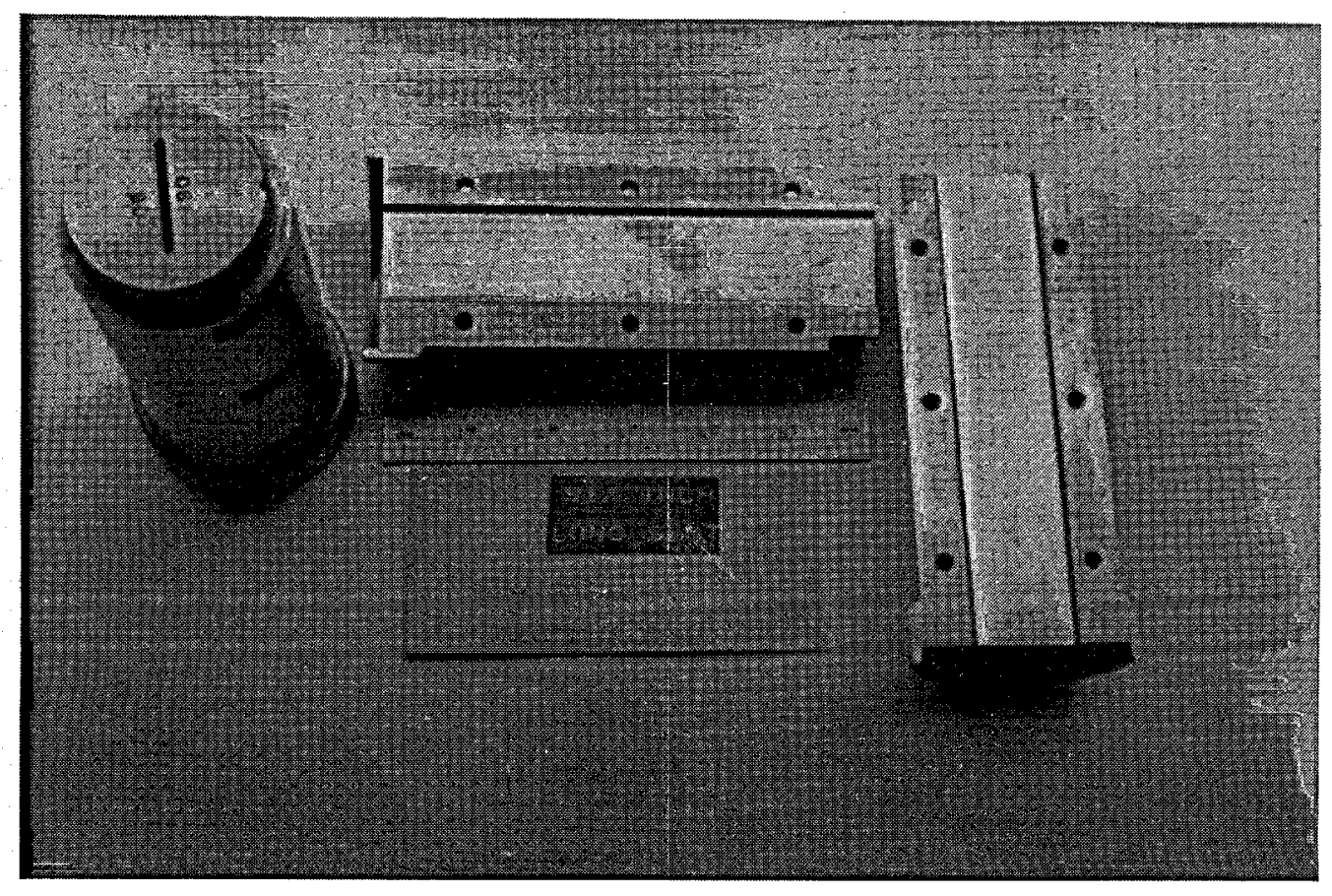

Figure 8. Six Inch Long Slot

Non-standard tapered slots were also fabricated to be used in place of the modified long slots as shown in Figure 9. Eight different tapered slots were fabricated and dimensions of these slots are shown in Table 1.

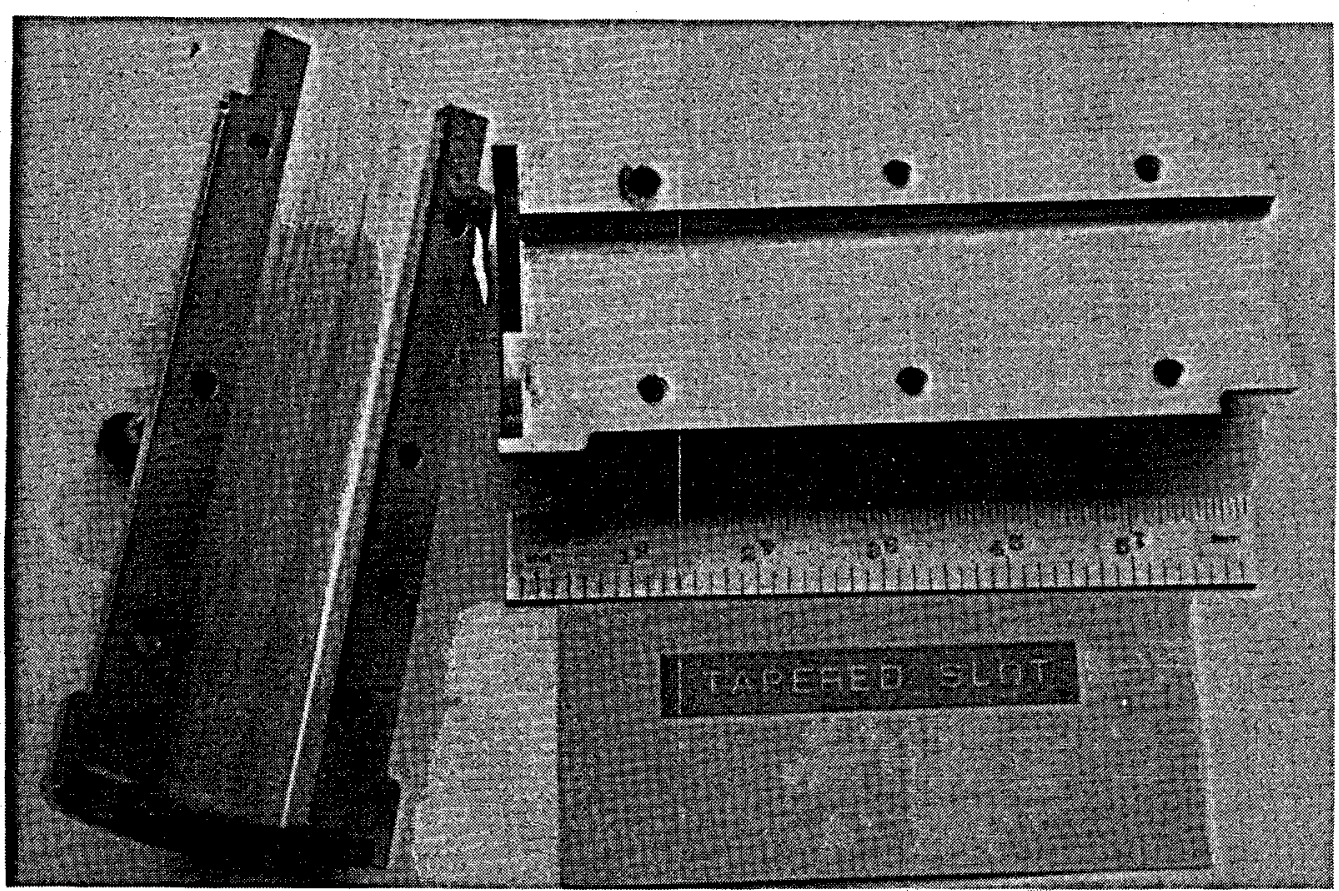

Figure 9. Tapered S1ot 
Table 1. Tapered Slots

S1ot Designation Inlet Width (in) Outlet Width (in)

$\begin{array}{rll}010 & 0.120 & 0.080 \\ 011 & 0.160 & 0.080 \\ 012 & 0.160 & 0.120 \\ 013 & 0.200 & 0.120 \\ 014 & 0.200 & 0.160 \\ 03 & 0.500 & 0.250 \\ 04 & 0.750 & 0.250 \\ 05 & 0.750 & 0.500\end{array}$

In all cases the remaining slot dimension perpendicular to the flow direction was 1.25 in.

C. Slurry Preparation

The LCM was mixed to desired concentrations with a bentonite mud system (specified by API RP13B) whose material properties are noted in Table 2 .

Table 2. Bentonite Mud

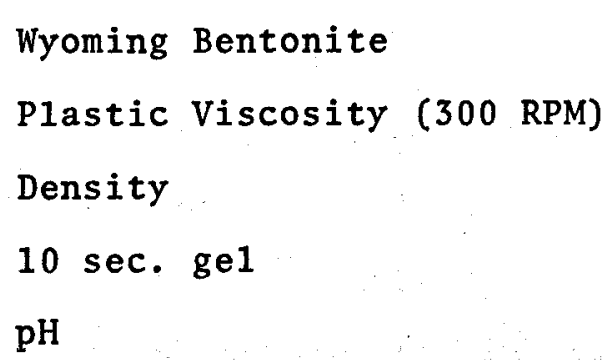

5-8\% by weight $25 \mathrm{cp} \pm 2 \mathrm{cp}$

$8.8 \mathrm{ppg}$

$9-361 \mathrm{~b}_{\mathrm{m}} / 100 \mathrm{ft}^{2}$

8.2-9.2

During the course of testing, significant scatter in the sealing pressure data were observed. In attempts to rule out laboratory-induced scatter in the data, several modifications to the mixing procedure were attempted. These included sample quartering, simple shear mixing, and slurry soaking.

The possibility that solid particle segregation in the LCM was responsible for data scatter was examined by a standard mounding and quartering technique. In order to rule out the possibility that solid LCM particles might have a significantly different size distribution 
between various solid samples, a sample of LCM, which was four times that required for a single run, was thoroughly mixed in a large $j$ ar. This well mixed solid sample was then poured out onto a table in such a way that a small stream of particles was dropped over the same location on the table. The resultant cone which was built up would be expected to have some vertical segregation of particles, but no angular variation about the axis of the cone. This cone was then divided by passing a cardboard sheet vertically down the axis of the cone and separating the original cone into two halves. Repeating this procedure a right angle to the first division than gave four samples of approximately equal size, but more importantly, with more nearly equal particle distribution. These four samples were then weighed and mixed with the appropriate amounts of mud to form identical slurries. The results of these tests are given later in the report.

A second modification of the mud-LCM slurry preparation technique is the Couette mixing technique. In order to more realistically simulate the shear fields which a mud-LCM slurry will experience in being pumped from the surface to a lost circulation zone, a typical test case is considered. Assume that the loss circulation zone is $3000 \mathrm{ft}$ below the surface and that the pumping rate is $400 \mathrm{gpm}$. For $4-1 / 2 \mathrm{in}, 16.60$ $1 \mathrm{~b} / \mathrm{ft}$ drill pipe, the Reynolds number is calculated to be 14,000 , so that the flow is turbulent. It is desirable to approximate this fluid shear field in both intensity.and duration. Since pumping through $3000 \mathrm{ft}$ of pipe is not readily accomplished in the laboratory, it was decided to obtain similar shear fields by using a laboratory mixer. Since a standard mixer impeller may damage the particulates through its combination of shear and beating action, a right circular cylinder was fabricated to provide a simple shearing action as shown in Figure 10 . 


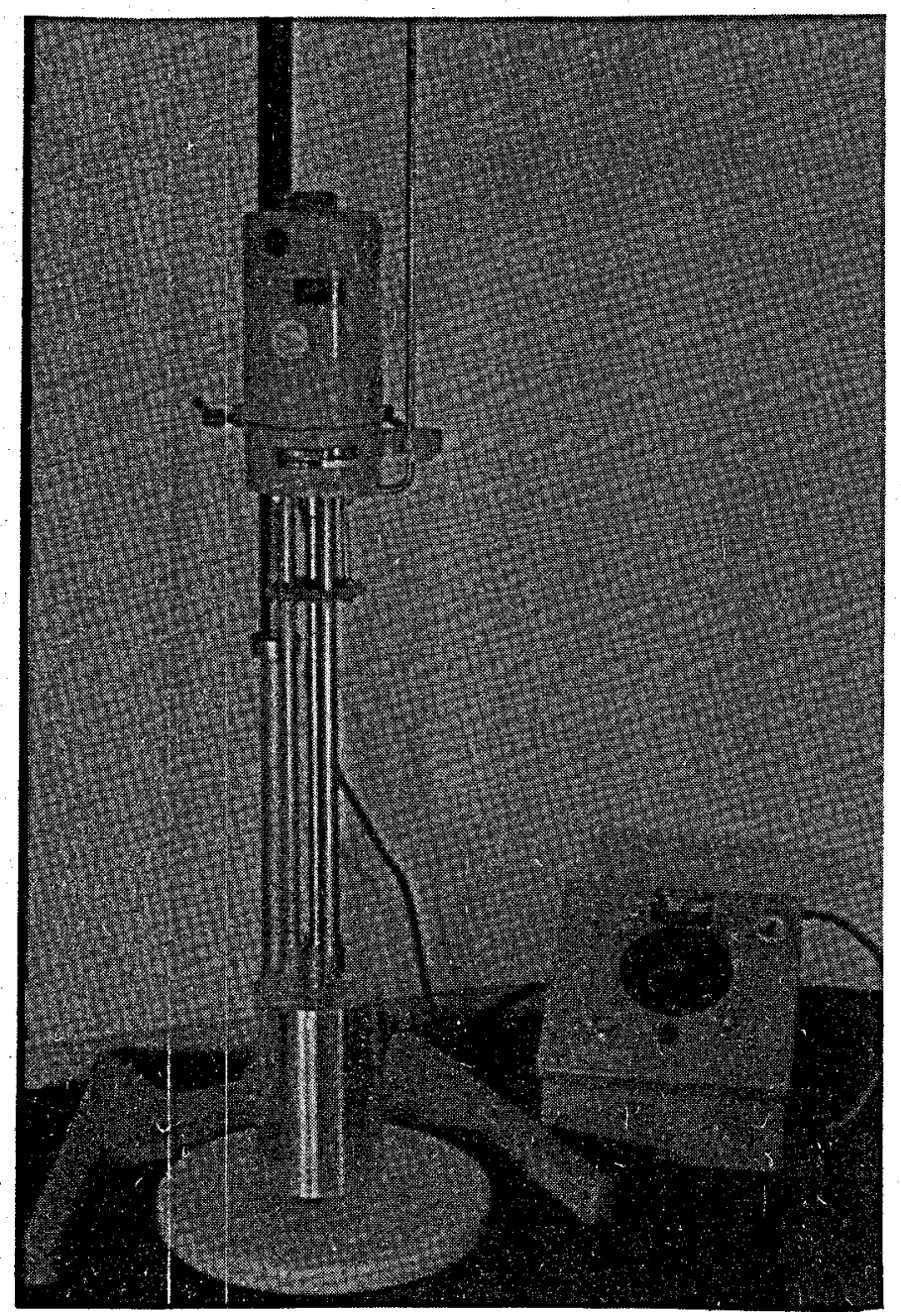

Figure 10. Couette Mixer Composed of a Right Circular Cylinder Fitted to a Standard Laboratory Mixer

In order to define the size and rotational speed of the cylindrical mixer, the pipe Reynolds number was matched to the Reynolds number for mixing in a large tank,

$$
\mathrm{Re}_{\mathrm{m}}=\frac{\mathrm{D}^{2} \mathrm{~N} \rho}{\mu}
$$

where $\mathrm{Re}_{\mathrm{m}}$ is the mixing Reynolds number, $\mathrm{D}$ is the mixer diameter, $\mathrm{N}$ is the rotational speed in revolutions/sec, $\rho$ is the density and $\mu$ is the viscosity. As may be seen from Equation (1), $\mu$ and $\rho$ are determined by the fluid properties, and $\mathrm{Re}_{\mathrm{m}}$ is set equal to 14,000 , so that $\mathrm{D}$ and $\mathrm{N}$ 
are the only variables. If $D$ is $1 \mathrm{in}$, then $N$ is $158 \mathrm{rev} / \mathrm{sec}$, whereas if $D$ is 4 in then $N$ is $32 \mathrm{rev} / \mathrm{sec}$. Additionally, if we require that the maximum fluid velocity in the mixer be approximately the same as that which occurs in the drill pipe, then the 4 in diameter mixer is to be preferred. Accordingly, the Couette mixer used in this work was 4 in in diameter and extended through the complete depth of the slurry to be mixed.

The mixing time is defined to be equal to the transit time for the slurry to traverse $3000 \mathrm{ft}$ of dri11 pipe at $400 \mathrm{gpm}$. The average fluid velocity is

$$
V=\frac{Q}{A}
$$

where $Q$ is $400 \mathrm{gpm}$ and $A$ is $0.0798 \mathrm{ft}^{2}$, the cross sectional area of a 4-1/2 in $16.60 \mathrm{lb} / \mathrm{ft}$ dril1 pipe. Hence, $V$ is $11.16 \mathrm{ft} / \mathrm{sec}$ and the transit time, $\theta$, is

$$
\theta=\frac{3000 \mathrm{ft}}{11.16 \mathrm{ft} / \mathrm{sec}}=269 \mathrm{sec}=4.5 \mathrm{~min}
$$

The mixing which occurs through a triplex pump is also briefly considered. The flow area through the valves may vary between typical values 5.75 and 11.5 in $^{2}$ depending on the pump choice and flow rate. 5 In the former case the total flow area through the pump is 17.25 in ${ }^{2}$ and 34.5 in $^{2}$ in the latter case. These cases correspond to Reynolds numbers through the pump of 22600 and 16000. While these high Reynolds numbers indicate high turbulence through the pump, they are of extremely short duration and are of the the same order of magnitude as the Reynolds number which occurs in the pipe. Hence, the mixing which occurs as a result of the transit through the pump is not simulated separately.

The third variable in the mixing process which was investigated was the soak time. Early in the test program when the test procedure was being refined, the mud-LCM slurry stood for a variable amount of 
time (hereafter referred to as "soak time") before being tested. Some apparent dependence of the LCM performance on this soak time was noted and investigated briefly. Because of the scatter in the maximum sealing pressure, no specific conclusions could be drawn from the variations of soak time, but in order to minimize any effect from this variable, subsequent samples were allowed to soak for ten minutes before being run through the tester.

The effect of higher temperatures on the lost circulation material was also investigated. In these tests, sample slurries were aged at either $250^{\circ} \mathrm{F}$ or $400^{\circ} \mathrm{F}$ in a Baroid roller oven capable of heating samples as high as $450^{\circ} \mathrm{F}$ in $500 \mathrm{~m} 1$ pressurized cells. Mixtures of LCM and bentonite mud were poured into 8 cells and overpressured with 50 psi $\mathrm{N}_{2}$ to prevent boiling and then placed into the roller oven. The cells were brought to the designated temperature and held there for four hours. They were then allowed to cool in air to ambient temperature before being depressurized and poured into the lost circulation tester. During the course of this heating cycle, the mud could react with the LCM and would undergo significant gel formation. The results of these tests are presented below.

D. Test Sequence

The API prescribed test sequence is described in RP13B; following is a summary of this procedure. The test is conducted by pouring the LCM-mud mixture into the reservoir with the outlet valve closed and a slot of specified width in place. A piston to separate nitrogen driving pressure from the drilling fluid mixture is emplaced. The cap is screwed onto the reservoir and the outlet valve is then opened. With only hydrostatic pressure acting, the amount of fluid passing is recorded. The pressure on the mud-LCM slurry is then increased at a rate of $2 \mathrm{psi} / \mathrm{sec}$ until $100 \mathrm{psi}$ is reached. At this time, the volume of effluent fluid is recorded. If the seal breaks prior to reaching $100 \mathrm{psi}$, the break- 
down pressure is recorded. If the seal is still holding, the pressure is then increased to $1000 \mathrm{psi}$ at a rate of $10 \mathrm{psi} / \mathrm{sec}$. The volume of effluent fluid is recorded at $500 \mathrm{psi}$ and $1000 \mathrm{psi}$, if possible, or the breakdown pressure is recorded if that occurs. If the seal holds at 1000 psi, the pressure is maintained for 10 minutes prior to terminating the test and disassembling the apparatus.

Upon termination of the test, the seals which were formed are visually examined to determine the location of the seal and the character of the particle interaction. In every case the seals were observed at the face of the test slots as shown in Figure 11 for the case of Kwik-Seal at $5 \mathrm{ppb}$.
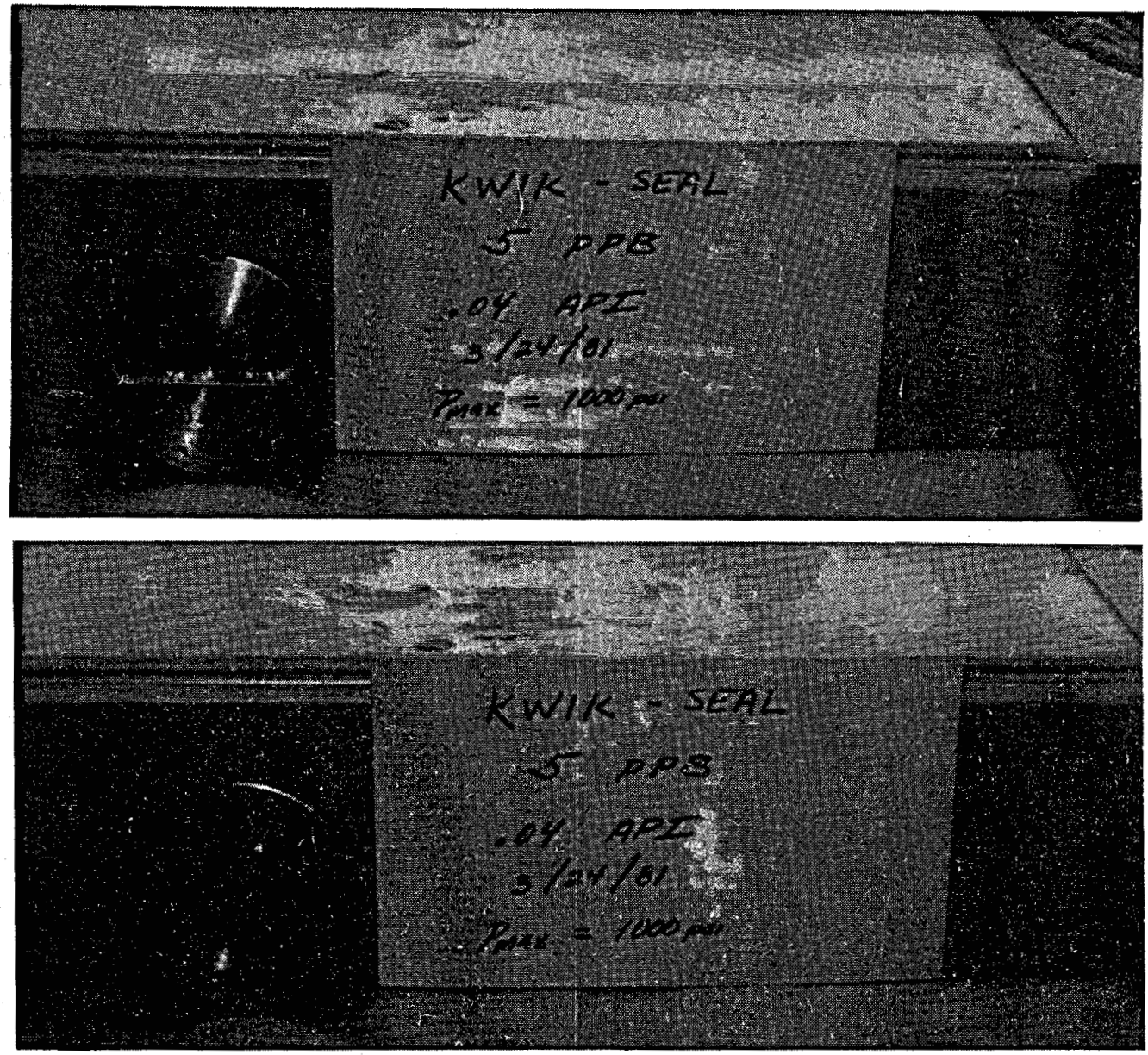

Figure 11. Face seal of Kwik-Seal at $5 \mathrm{ppb}$ on a 0.04 in API slot. Top view is of back side of seal and bottom view is of the front of the seal. Some strands of the fibrous component are seen on the rear side of the plug while the majority of the plug is on the face. 


\section{E. Results}

1. Data

of the six materials tested in these experiments, the most extensive testing was performed on cottonseed hulls, Kwik-Seal, and Ruf-Plug. The results of the tests performed with paper pulp are given in Table 3 . In Tables 3 through 13, each tabulated maximum sealing pressure is the output from one test. LCM slurry concentrations were selected to be consistent with those used in the field.

Table 3. Paper Pulp - Lost Circulation Tests

\begin{tabular}{ccc}
$\begin{array}{c}\text { Material Concentration } \\
(\text { lb/bbl) }\end{array}$ & $\begin{array}{c}\text { Slot Size } \\
\text { (in) }\end{array}$ & $\begin{array}{c}\text { Maximum Sealing Pressure } \\
\text { (psi) }\end{array}$ \\
\cline { 1 - 1 } 5 & 0.04 & 0 \\
10 & 0.04 & 72 \\
15 & 0.04 & 60 \\
10 & 0.06 & 40
\end{tabular}

The results of the tests performed with cottonseed hulls are given in Tables 4 and 5 . The results of the tests performed with Kwik-Seal are given in Tables 6 and 7 and those for Ruf-Plug in Tables 8, 9, and 10. In Tables 4 through 10 each entry of maximum sealing pressure represents one run and $(*)$ indicates that 6 in long slots were used.

Table 4. Cottonseed Hulls-Lost Circulation Tests Concentration of Cottonseed Hulls - $51 \mathrm{~b} / \mathrm{bbl}$.

Slot Size (in) Maximum Sealing Pressure (psi)

$0.04 \quad 950$

$0.06 \quad 275,1000,1000$

$0.08 \quad 750,550,1000,1000,1000,950 *, 1000^{*}, 1000$

$0.12 \quad 760,880,530,1000,460,1000,840,1000,980$, $720^{*}, 520^{*}, 500^{*}, 720^{*}, 900 *, 500^{*}$

$0.16 \quad 500,1000,1000,450,530,770,730,450,700 *$,

$0.20 \quad 475,770,50,0,420,480,640,430,430 *, 530^{*}$, $310^{*}, 500 *$

$0.25280^{*}$ 
Table 5. Cottonseed Hulls--Lost Circulation Tests Concentration of Cottonseed Hulls - $10 \mathrm{lb} / \mathrm{bb} 1$.

\begin{tabular}{|c|c|}
\hline slot Size (in) & Maximum Sealing Pressure (psi) \\
\hline 0.04 & $99 p$ \\
\hline 0.06 & 950 \\
\hline 0.08 & 1000 \\
\hline 0.12 & $\begin{array}{l}990,990,840,1000,960 *, 730 *, 1000 * \\
1000 *, 1000 *\end{array}$ \\
\hline 0.16 & $\begin{array}{l}660,940,1000,720,840,620,710^{*}, 1000^{*}, \\
660^{*}, 720^{*}, 650^{*}, 600\end{array}$ \\
\hline 0.20 & $\begin{array}{l}825,660,800,600,650,760,790^{*}, 1000^{*}, \\
730^{*}, 390^{*}, 480^{*}, 650^{*}, 650^{*}\end{array}$ \\
\hline Table 6 . & $\begin{array}{l}\text { Kwik-Sea1--Lost Circulation Tests } \\
\text { Concentration of Kwik-Sea1- } 51 \mathrm{~b} / \mathrm{bbl} \text {. }\end{array}$ \\
\hline Slot Size (in) & Maximum Sealing Pressure (psi) \\
\hline 0.04 & 1000 \\
\hline 0.06 & 1000 \\
\hline 0.08 & $850,930,830,1000^{*}, 810^{*}, 1000^{*}$ \\
\hline 0.12 & $\begin{array}{l}150,300,140,0^{*}, 100^{*}, 1000^{*}, 280^{*}, 90^{*}, \\
500^{*}, 650^{*}, 72^{*}, 150^{*}, 830^{*}, 40^{*}, 700^{*}, 700^{*}\end{array}$ \\
\hline 0.16 & $0,150,56^{*}, 220^{*}, 0^{*}, 780^{*}, 500^{*}$ \\
\hline 0.20 & 10 \\
\hline
\end{tabular}


Table 7. Kwik-Sea1--Lost Circulation Tests Concentration of Kwik-Seal - $101 \mathrm{~b} / \mathrm{bbl}$.

Slot Size (in) Maximum Sealing Pressure (psi)

$0.06 \quad 1000$

$0.08 \quad 1000,1000$

$0.12430,72,1000,1000,780^{*}, 310^{*}, 1000^{*}$, $1000^{*}, 500^{*}, 500^{*}, 1000^{*}$

$0.1486^{*}, 1000^{*}, 490^{*}, 290^{*}, 180^{*}, 900^{*}, 800^{*}$

$0.161000,1000,1000,1000,1000 *, 1000 *$, $990 *, 920 *, 590 *, 200 *, 80 *$

$0.201000,0,1000,0 *, 92 *, 960 *, 1000 *$, $200^{*}, 0^{*}, 770^{*}, 370^{*}, 630^{\star}, 1000$

0.25

0 *

Table 8. Ruf-Plug--Lost Circulation Tests

Concentration of Ruf-Plug - $101 \mathrm{~b} / \mathrm{bbl}$.

Slot Size (in) Maximum Sealing Pressure (psi)

$0.04 \quad 1000$

$0.06 \quad 1000,1000,1000$

$0.08 \quad 460,305,450,620^{*}, 730^{*}, 590^{*}, 470^{*}, 420^{*}$

$0.120,20 *, 22 *, 20 *$ 
Table 9. Ruf-Plug--Lost Circulation Tests

Concentration of Ruf-Plug - $30 \mathrm{lb} / \mathrm{bb} 1$.

Slot Size (in) Maximum Sealing Pressure (psi)

$0.06 \quad 1000$

$0.08680,580,960^{*}, 660^{*}, 900^{*}, 770^{*}, 1000^{*}, 1000^{*}$, $260^{*}, 200^{*}, 110^{*}, 0 *, 84^{*}, 0 *, 34 *, 0 *, 1000^{*}$ $0.12 \begin{aligned} & 90,84,460^{*}, 300^{*}, 360^{*}, 430^{*}, 430^{*}, 230^{*}, \\ & 220^{*}, 180^{*}, 80^{*}, 195^{*}, 310^{*}, 470^{*}\end{aligned}$

$0.1634,32,98^{*}, 160^{*}, 680^{*}, 350^{*}, 180^{*}, 70^{*}, 0^{*}$

$0.20 \quad 170,100$

Table 10. Ruf-Plug--Lost Circulation Tests

Concentration of Ruf-Plug - $601 \mathrm{~b} / \mathrm{bb} 1$.

Slot Size (in) Maximum Sealing Pressure (psi)

$0.12 \quad 1000$

$0.20900,880,950,780,0$

The results of the tests performed on ground battery casings are shown in Table 11. As seen in Table 11, this material exhibited large filtrate losses. Hence, a very fine particle size material, flaked Micatex, was added to assist in filtrate control. 
Table 11. Ground Battery Casings--Lost Circulation Tests

\begin{tabular}{|c|c|c|c|c|}
\hline $\begin{array}{c}\text { Particle Size } \\
\text { Range }\end{array}$ & $\begin{array}{c}\text { Material } \\
\text { Concentration } \\
(1 \mathrm{~b} / \mathrm{bb} 1) \\
\end{array}$ & $\begin{array}{l}\text { Slot } \\
\text { Size } \\
\text { (in) } \\
\end{array}$ & $\begin{array}{l}\text { Maximum } \\
\text { Sealing } \\
\text { Pressure } \\
\text { (psi) } \\
\end{array}$ & $\begin{array}{c}\text { Filtrate } \\
\text { from } \\
\text { Successfu1 } \\
\text { Seal (mI) } \\
\end{array}$ \\
\hline coarse & 20 & 0.20 & 1000 & 500 \\
\hline coarse & 10 & 0.20 & 660 & -- \\
\hline coarse & 10 & 0.16 & 1000 & 850 \\
\hline fine & 10 & 0.04 & 0 & $\cdots$ \\
\hline fine & 20 & 0.04 & 0 & $-\ldots$ \\
\hline medium & 10 & 0.04 & 1000 & 300 \\
\hline medium & 10 & 0.06 & 1000 & 1950 \\
\hline medium & 10 & 0.08 & 1000 & 1350 \\
\hline medium & 10 & 0.08 & 1000 & 2250 \\
\hline medium & 10 & 0.12 & 0 & $\cdots$ \\
\hline medium & 10 & 0.12 & 0 & $\ldots$ \\
\hline medium & 20 & 0.12 & 0 & $\ldots$ \\
\hline dium + micatex* & $5 / 5$ & 0.08 & 1000 & 1550 \\
\hline medium + micatex & $5 / 5$ & 0.12 & 0 & $-\ldots$ \\
\hline
\end{tabular}

* $5 \mathrm{lb} / \mathrm{bbl}$ micatex were mixed with $5 \mathrm{lb} / \mathrm{bb} 1$ ground battery casing. 
Data gathered using tapered slots are presented in Table 12.

Table 12. Tapered S1ot--Lost Circulation Tests

\begin{tabular}{|c|c|c|c|c|}
\hline Material & $\begin{array}{c}\text { Concentration } \\
1 \mathrm{~b} / \mathrm{bb} 1 \\
\end{array}$ & $\begin{array}{r}\text { Slot } \\
\text { inlet }\end{array}$ & $\begin{array}{l}\text { Size } \\
\text { outlet }\end{array}$ & $\begin{array}{l}\text { Maximum Sealing } \\
\text { Pressures (psi) }\end{array}$ \\
\hline Kwik-Seal & 5 & 0.16 & 0.08 & 1000 \\
\hline Kwik-Sea1 & 5 & 0.12 & 0.08 & 740 \\
\hline Kwik-Sea1 & 5 & 0.12 & 0.08 & 650 \\
\hline Kwik-Sea1 & 5 & 0.12 & 0.08 & 910 \\
\hline
\end{tabular}

The results of temperature aged tests are presented in Table 13.

Table 13. Temperature Aged--Lost Circulation Tests

\begin{tabular}{|c|c|c|c|c|}
\hline Material & $\begin{array}{c}\text { Concentration } \\
(1 \mathrm{~b} / \mathrm{bb} 1) \\
\end{array}$ & $\begin{array}{l}\text { Slot Size } \\
\text { (in) }\end{array}$ & $\begin{array}{c}\text { Aging } \\
\text { Temperature } \\
\left({ }^{\circ} \mathrm{F}\right) \\
\end{array}$ & $\begin{array}{l}\text { Maximum Sealing } \\
\text { Pressure (psi) }\end{array}$ \\
\hline $\begin{array}{l}\text { Cottonseed } \\
\text { Hulls }\end{array}$ & 5 & 0.06 & 250 & 380 \\
\hline Kwik-Sea1 & 5 & 0.06 & 250 & 1000 \\
\hline Kwik-Seal & 5 & 0.06 & 400 & 710 \\
\hline Ruf-Plug & 10 & 0.06 & 250 & 1000 \\
\hline Ruf-P1ug & 10 & 0.06 & 400 & 30 \\
\hline $\begin{array}{l}\text { Battery } \\
\quad \text { Casing }\end{array}$ & 10 & 0.08 & 400 & 1000 \\
\hline $\begin{array}{l}\text { Battery } \\
\text { Casing }\end{array}$ & 10 & 0.12 & 400 & 400 \\
\hline $\begin{array}{l}\text { Battery } \\
\quad \text { Casing/Mi }\end{array}$ & icatex $^{5 / 5}$ & 0.08 & 400 & 1000 \\
\hline
\end{tabular}




\section{ANALYSIS}

A significant amount of scatter exists. Since the scatter was so large, it is essential to determine if this variability in the data is attributable to errors in measurement technique. Two possibilities for experimentally induced error were identified. The first possibility was that particles of lost circulation material were inconsistently broken down in the slurry preparation technique. The second possibility was that there was significant variation in the particle size distribution between test runs.

A test of the effect of mixing was made with Ruf-Plug at $301 \mathrm{~b} / \mathrm{bb} 1$ using 0.08 and 0.12 in slots. Most data in these runs were gathered using slurries which were allowed to soak 15 minutes prior to testing. These slurries would appear lumpy when this soaking period and a brief stirring period were finished. The mixing technique described in Section II-C was used in a number of runs. The results of these runs are excerpted from Table 9 and are presented in Table 14.

Table 14. Effect of Mixing on Maximum Sealing Pressure of Ruf-Plug at $301 \mathrm{~b} / \mathrm{bbl}$

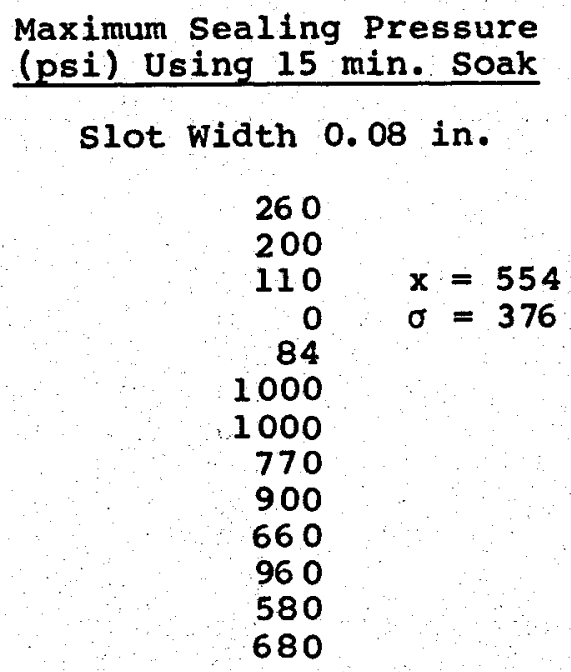

$$
x=554
$$$$
\sigma=376
$$

slot Width 0.12 in.

$\begin{array}{rl}90 & \\ 84 & x=308 \\ 460 & \sigma=160 \\ 300 & \\ 430 & \end{array}$

Maximum Sealing Pressure (psi) Using Mixing Technique

slot Width 0.08 in.

$$
\begin{array}{rl}
0 & \\
34 & x=259 \\
0 & \sigma=495 \\
1000 &
\end{array}
$$

slot width 0.12 in.

$$
\begin{array}{r}
230 \\
220 \\
180 \\
80 \\
195
\end{array}
$$


Table 14 also shows the means and standard deviations for the results presented. From the data it is seen that the mean maximum sealing pressure does decrease when the slurry is subjected to a mixing process similar to that which occurs in being pumped through $3000 \mathrm{ft}$ of drill pipe. However, the standard deviations are still large, and with the given analyses it is difficult to say whether mixing has any effect. Hence, a standard analysis of variance (see Appendix) was performed on this data and the results of this analysis are presented later in the report.

Similarly, a check on the possibility of having poorly sorted particles was made by mounding enough material for four tests and then quartering the resulting cone to give four identical samples. Each sample was then run under identical conditions and the results compared to the other runs within that group as shown in Table 15 for Ruf-P1ug at $30 \mathrm{ppb}$ in a 0.12 in slot.

Table 15. Effect of Particle Sorting on Maximum Sealing Pressure of Ruf-Plug at $30 \mathrm{1b} / \mathrm{bb} 1$ in 0.12 in Slot

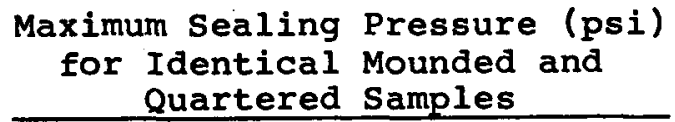
Quartered Samples Maximum Sealing Pressure (psi) for All Other Samples Using Ruf-Plugie at $30 \mathrm{lb} / \mathrm{bbl}$ in 0.12 in. slot

$\begin{array}{rrr}80 & & 90 \\ 195 & x=264 & 84 \\ 310 & \sigma=167 & 460 \\ 470 & & 300 \\ & & 430 \\ & 430 \\ & 360 \\ & 230 \\ & 220 \\ & 180\end{array}$

These data reveal almost no difference in mean values and lead to the conclusion that particle sorting does not significantly contribute to the observed data scatter. This conclusion will be further supported by an analysis of variance described in the Appendix. 


\section{A. ANOVA on Mixing and Sorting Data}

An analysis of the mixing data was performed. The values of the

error variance, $s_{e}^{2}$, and the variance of the means, $s^{2}{ }^{2} m$ as well as the $F$ value for the data presented in Table 14 for the 0.08 in slot widths are presented below.

$$
\begin{aligned}
s_{e}^{2} & =161826 \\
s_{p}^{2} m & =55955 \\
n_{0} & =6.1176 \\
s_{p}^{2} & =342314 \\
F & =\frac{s_{p}^{2}}{s_{e}^{2}}=2.115
\end{aligned}
$$

Since the $F$ value is greater than one for this data, the $F$ value must then be compared to distributions of $F$ to see if the effect of mixing has any real effect on the maximum sealing pressure. Tabulated values of F for different sample sizes are given in Mickley, Sherwood and Reed $^{6}$ and for a comparison of 17 different data points and an average sample size of 6.12 , F must be larger than 8.68 for $99 \%$ confidence and 4.54 for $95 \%$ confidence that the whole effect of mixing is not a random effect.

A similar comparison on the mixing data obtained using Ruf-Plug in 0.12 in slots reveals that the value of $F$ is 0.776 . In this case the error variance is actually larger than the variance arising from the difference in the means. Hence, it is concluded that the effect of mixing is too small to be distinguished from other factors causing experimental variations in the maximum sealing pressure.

A similar comparison of the sorting data presented in Table 15 reveals that $F$ is 0.034 . This very low value of $F$ is a consequence of the closeness of the results obtained by either using sorted or non-sorted 
samples. In conclusion, it may be positively stated that neither mixing or sorting explain the large amount of experimental error observed in the data. Since other experimental variables are similar between runs, this leads to the conclusion that the random nature of plug formation mechanics plays a dominant role in the variation of maximum sealing pressure from run to run.

B. Comparisons of Maximum Sealing Pressure with Standard API Slots and 6 Inch Long Slots

A comparison between the mechanics of sealing of LCM in API slots and 6 in long extended slots was also carried out in the tests presented in Tables 4 through 9. Those data which were obtained in experiments where 6 in long slots were used are denoted by an asterisk (*). Means and standard deviations were computed for each test and F-tests were performed. The results of these comparisons are presented in Tab1e 16.

Table 16. Comparison of Maximum Sealing Pressure Obtained with API Slots and 6 Inch Long Slots

\begin{tabular}{|c|c|c|c|c|c|c|c|c|}
\hline Material & $\begin{array}{c}\text { Conc. } \\
(1 \mathrm{~b} / \mathrm{bbi})\end{array}$ & $\begin{array}{l}\text { Slot Width } \\
\text { (in) }\end{array}$ & API & $\begin{array}{c}\text { No. of Data } \\
\text { Points }\end{array}$ & $\begin{array}{c}\text { Mean Max. } \\
\text { Sealing Press. }\end{array}$ & $\begin{array}{c}\text { Std. } \\
\text { Deviation }\end{array}$ & $\mathbf{F}$ & $\begin{array}{c}958 F \\
\begin{array}{c}958 \text { Fificant } \\
\text { Level }\end{array} \\
\end{array}$ \\
\hline CSH & 5 & 0.12 & $\begin{array}{l}\text { API } \\
\text { Long }\end{array}$ & $\begin{array}{l}9 \\
6\end{array}$ & $\begin{array}{l}828 \\
643\end{array}$ & $\begin{array}{l}207 \\
164\end{array}$ & 3.47 & 4.67 \\
\hline CSH & 5 & 0.16 & $\begin{array}{l}\text { API } \\
\text { Long }\end{array}$ & $\begin{array}{l}8 \\
6\end{array}$ & $\begin{array}{l}679 \\
553\end{array}$ & $\begin{array}{l}232 \\
553\end{array}$ & .346 & 4.75 \\
\hline CSH & 10 & 0.16 & $\begin{array}{l}\text { API } \\
\text { Long }\end{array}$ & $\begin{array}{l}6 \\
6\end{array}$ & $\begin{array}{l}797 \\
723\end{array}$ & $\begin{array}{l}155 \\
142\end{array}$ & .731 & 4.96 \\
\hline Kwik-Seal & 5 & 0.08 & $\begin{array}{l}\text { API } \\
\text { Long }\end{array}$ & $\begin{array}{l}3 \\
3\end{array}$ & $\begin{array}{l}870 \\
937\end{array}$ & $\begin{array}{r}53 \\
110\end{array}$ & .897 & 7.71 \\
\hline Kwik-Seal & 10 & 0.12 & $\begin{array}{l}\text { API } \\
\text { Long }\end{array}$ & 4 & $\begin{array}{l}626 \\
727\end{array}$ & $\begin{array}{l}456 \\
290\end{array}$ & 0.225 & 5.12 \\
\hline Ruf-Plug & 10 & 0.08 & $\begin{array}{l}\text { API } \\
\text { Long }\end{array}$ & $\begin{array}{l}3 \\
5\end{array}$ & $\begin{array}{l}405 \\
566\end{array}$ & $\begin{array}{r}87 \\
123\end{array}$ & 4.04 & 5.99 \\
\hline Ruf-Plug & 30 & 0.08 & $\begin{array}{l}\text { API } \\
\text { Long }\end{array}$ & $\begin{array}{r}2 \\
15\end{array}$ & $\begin{array}{l}630 \\
465\end{array}$ & $\begin{array}{r}71 \\
434\end{array}$ & .430 & 4.54 \\
\hline
\end{tabular}

As may be seen in Table 16, the inconsistency of the data manifests itself even in statistical interpretation. In most cases the value of $F$ is less than one indicating that there is no difference between the sealing pressure obtained with API slots and 6 in long slots. Similarly, in those cases where values of $\mathrm{F}$ greater than unity were obtained, there is no statistically significant difference in sealing pressure between 
API and 6 in long slots at the 95\% confidence levels. This is evidenced by the fact that the computed values of $F$ are always less than the tabulated $95 \%$ confidence levels.

Further corroboration for the tenet that long slots and API slots give identical experimental results is obtained from the visual observation that sealing with LCM takes place on the leading edge of either the API slot or the 6 in long slot. In the case of front face sealing, the longer slots would not be expected to lead to higher sealing pressures, as they may if other sealing mechanisms were being investigated.

C. Comparison of Tapered Slot Sealing Data to Straight Slot Data Data obtained with tapered slots, presented in Table 12, may be compared to similar data obtained with the same material, Kwik-Seal at $51 \mathrm{~b} / \mathrm{bb} 1$, presented in Table 6 . In this case it is observed that the scatter observed in the data with straight slots may be reconciled to sealing at either the front or the rear of the tapered slots. The first tapered slot shown in Table 12 had an opening which varied between 0.16 in at the inlet and 0.08 in at the outlet and exhibited a maximum sealing pressure of $1000 \mathrm{psi}$. The other tapered slot runs were conducted in slots with 0.12 in inlets and 0.08 in outlets and had maximum sealing pressures in the range of 740 to $910 \mathrm{psi}$. Since straight slots sealed between 810 and $1000 \mathrm{psi}$ in 0.08 in slots, 0 and $1000 \mathrm{psi}$ in 0.12 in slots, and 0 to $780 \mathrm{psi}$ in 0.16 in slots, it is difficult to say whether these tapered slots behaved as would be characteristic of $0.08 \mathrm{in}, 0.12 \mathrm{in}$, or 0.16 in slots or at some intermediate value. Additionally, since none of the tapered slots retained its seal at the conclusion of the test, visual inspection of the plug formed was not possible. Hence, no conclusions about modification of plug formation mechanics as a consequence of using tapered slots may be reached at this time. 


\section{Effect of LCM Concentration on Sealing Ability}

Different concentrations within the normally used range of concentrations for cottonseed hulls, Kwik-Seal, and Ruf-Plug were tested. In each case increasing the concentration of the LCM increased the average maximum sealing pressure. However, the random nature of the sealing pressure was so strong that runs made at higher concentrations sometimes had lower sealing pressures than runs made at lower concentrations, all other factors being equal.

It is also observed that increasing the concentration does not seem to affect the random nature of the plug formation mechanics. As shown in Table 10 this randomness persists even to concentrations as great as $60 \mathrm{lb} / \mathrm{bbl}$ for Ruf-Plug in a 0.20 in slot, where variations between 0 and 950 psi were observed.

E. Effect of Slot Size on Sealing Ability

For all of the materials tested it is observed that increasing the slot size leads to lower and less consistent sealing pressures. Consistent sealing pressures of $1000 \mathrm{psi}$ are obtained when the slot size is roughly equivalent to the largest rigid particle diameter in the LCM mixture. In cases, such as Kwik-Seal, where large flakes of flexible materials are present, these larger flexible materials do not consistently allow for sealing at slot sizes equivalent to thin particle diameters nor do they increase the effective rigid particle diameter for the purpose of consistent sealing. That this is true may be seen in the following table where the number of runs where the LCM sealed a given slot at $1000 \mathrm{psi}$ is compared to the total number of runs. 
Table 17. Comparison of Number of Runs Where Sealing at 1000 psi Occurred to Total Number of Runs

\begin{tabular}{|c|c|c|c|c|c|c|c|}
\hline$\checkmark$ & $\begin{array}{l}5 \text { with } \\
00 \text { psi }\end{array}$ & & MATI & $A L$ CONCENT & RATION (Ib & (bb1) & \\
\hline Total & & $\begin{array}{c}\text { CSH } \\
5 \\
\end{array}$ & $\begin{array}{l}\text { CSH } \\
10 \\
\end{array}$ & $\begin{array}{c}\text { KWIK-SEAL } \\
\mathbf{5}\end{array}$ & $\begin{array}{c}\text { KWIK-SEAL } \\
10\end{array}$ & $\begin{array}{c}\text { RUF-PLUG } \\
10\end{array}$ & $\begin{array}{c}\text { RUF-PLUG } \\
30\end{array}$ \\
\hline & .04 & & & & & & \\
\hline$\Xi$ & .06 & & L & \pm & $\stackrel{\perp}{2}$ & & \\
\hline ᄃ & .08 & & 1 & 6. & & & \\
\hline 苞 & .12 & 15 & 10 & $17 \times 2$ & $11 \quad 5$ & & \\
\hline 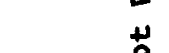 & .16 & 14 & 12 & 70 & 1116 & 0 & \\
\hline है & .20 & $12>$ & 13 & 10 & $13 \quad 3$ & & \\
\hline & .25 & 1 & 0 & & 10 & & 0 \\
\hline
\end{tabular}

For the three materials tested the approximate rigid particle diameter was .05 in. As may be seen in Table 17, when the slot width is $0.04 \mathrm{in}$, a consistent $1000 \mathrm{psi}$ seal was obtained. At higher concentrations of the LCM, Table 17 shows a slight increase in the consistent sealing range. For example, at $5 \mathrm{lb} / \mathrm{bb} 1$ cottonseed hu11s provided inconsistent sealing at 0.06 in while increasing the concentration to $10 \mathrm{1b} / \mathrm{bb} 1$ allowed slots up to 0.08 in to be sealed. It must be pointed out, however, that this increase in slot width sealing ability is supported by only a few tests and the effect is not 1arge. In the case of Kwik-Sea1, it is noted that the flexible flakes and fibers were as large as one centimeter, and these flexible materials did allow for inconsistent sealing in slots as large as 0.20 in. However, one must decrease the slot size to that of the rigid particles, 0.06 in, to obtain consistent 1000 psi sealing ability.

F. Effect of Temperature on Lost Circulation Materials (LCM)

As shown in Table 13, temperature has an adverse effect on the LCM derived from cellulosic products. Ambient tests of aged samples were run in the lost circulation slot tester with a 0.06 in slot where consistent sealing pressures had previously been obtained with samples 
which were not subjected to a high temperature heating cycle. In this case, it is seen that cottonseed hulls were severely affected at $250^{\circ} \mathrm{F}$ while Kwik-Seal and Ruf-Plug were still able to hold a 1000 psi seal. At $400^{\circ} \mathrm{F}$, however, Kwik-Seal was losing its ability to seal and Ruf-Plug retained virtually no sealing ability.

The effect of temperature on a non-cellulosic LCM was a1so tested. Ground battery casings were found to be unaffected at temperatures up to $400^{\circ} \mathrm{F}$. In fact this material, which was slightly lacking in fines, had lower filtrate loss at high temperature as a consequence of the increased gel strength of the temperature-aged mud. Although mud gellation is not sufficient to provide any significant assistance in bridging a fracture gap, it does appear to reduce the loss of whole mud through a LCM plug.

ANALYTICAL

A. Comparison Between Lost Circulation Bridging Materia1 P1ug Formation Mechanics and Permeability Impairment Mechanics

A comparison between the studies of LCM plug formation mechanics and permeability impairment mechanics in porous media is useful because both are hydrodynamically similar. The main conclusion of the latter studies, ${ }^{7,8}$ is that interactions of particles less than one-third of the fluid flow opening are unimportant. Indeed, this conclusion is consistent with data from the current study where it is observed that slot widths greater than three times the maximum rigid particle diameter produce no back pressure or resistance to flow.

There are also two notable differences between the studies of permeability impairment and LCM plug formation. Firstly, the formation permeability may be significantly impaired by multiple bridges throughout the volume of the porous rock so that each particle bridge will only have to support a small fraction of the total pressure drop. Since a LCM plug occurs primarily at the wellbore rock face, it will be required 
to support all of the total pressure load. Hence, the strength of the individual LCM plug is of far greater importance. Secondly, formation impairment studies are typically conducted with sand grains which have far greater tensile and shear strengths than the cellulosic particles which are typically used as LCM. Since this is the case, multiple particle bridges observed in impairment studies have sufficient strength, in the case of sand grains, to not be broken down by fluid pressure. In the case of cellulosic particles, it will be seen below that single particle bridges are strained to their limit in a typical fracture bridge and that multiple particle bridges are expected to be ineffective.

\section{B. Single Particle Bridge Strength}

In order to determine the maximum load which a plug spanning a fracture may support, consider the load carrying capacity of the bridge shown in Figure 12. If we assume that the plug spans a gap of width, $\ell$, and the height of the plug is also $\ell$, then it is possible to estimate the maximum stress in the plug when it is resisting a pressure, p. Using the analysis of a simply supported beam with uniformly distributed load $p$, the maximum stress in the plug at the midpoint, $c$, will be the tensile stress at the bottom of the plug and the compressive stress at the top of the plug. This stress is given by

$$
\sigma=\frac{M_{C} Y}{I}
$$

where $\sigma$ is the interior stress in the plug, $M_{c}$ is the moment of forces about the mid plane, $Y$ is the half-height $(\ell / 2)$ of the plug, and $I$ is the second moment of area. Ignoring end effects, the extent of the plug is unimportant and cancels out of the analysis. Substituting the appropriate quantities into equation (3), we obtain

$$
\sigma=\frac{3}{4} p
$$

If now we examine the properties of common cellulosic materials, we find that they typically have tensile strengths between 300 and $1000 \mathrm{psi}$ 
with 700 psi being an approximate average. ${ }^{9}$ Under these circumstances the maximum pressure which a cellulosic LCM may resist is of the order of $1000 \mathrm{psi}$. It is thus seen that the single particle lost circulation bridge is pressed to its structural limitation in severe lost circulation zones.

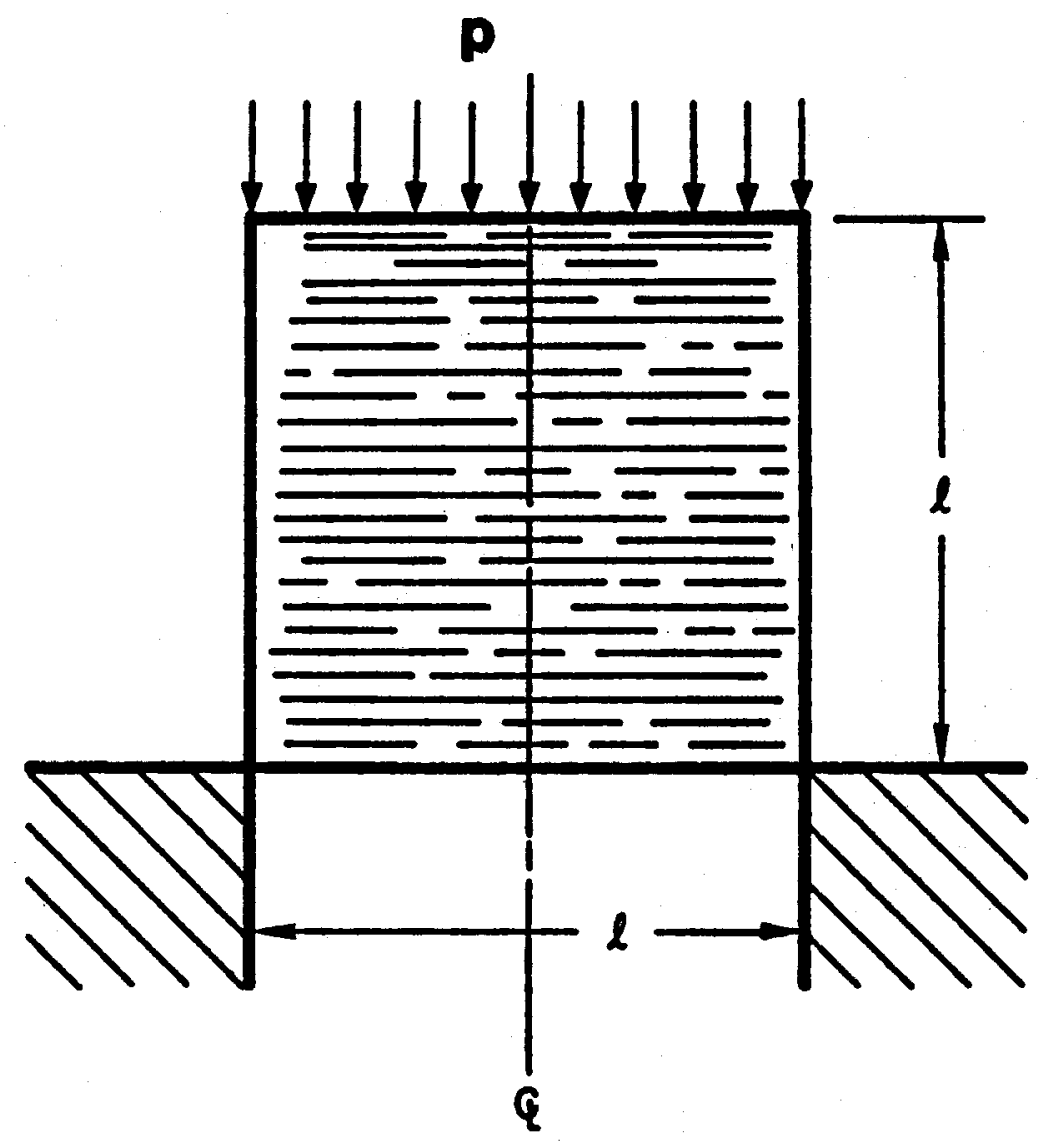

Figure 12. Single Particle Bridge. Lost circulation plug is assumed to bridge the gap of width l. The height of the particle is also $l$ and the applied pressure, $\mathrm{p}$, is uniformly applied. 


\section{Multi-Particle Bridge Strength}

The utility of multi-particle bridges is expected to be even less than single particle bridges. Since the shear, compressive, and tensile strengths of cellulosic particles average $1000 \mathrm{psi}^{9}$, and the crosssectional area of interlocking is intuitively expected to be much less than the cross-sectional area of the particle itself, it is anticipated that multi-particle interlocks will deform at lower pressures than those obtained above. This fact provides a rationale to explain the great amount of data scatter observed in maximum sealing pressure data. Since single particle bridges are stronger than multi-particle bridges, then

a plug composed with a higher proportion of single particle bridges will be stronger than one with a higher proportion of two or three particle bridges. Additionally, since a large number of smaller particles results from a typical crushing and grinding operation, the probability of smaller particle bridges becomes equivalent to or exceeds the probability of single particle bridges as the size of the gap to be bridged increases. Once the gap size exceeds the diameter of the largest particle in the distribution then single particle gaps are no longer possible and any seal will be dominated by the mechanics of multiparticle bridge formation.

For non-cellulosic LCM the strength of multi-particle bridges may be improved substantially. For example, the phenolformaldehyde resins and epoxys have shear strengths and tensile strengths an order of magnitude greater than the cellulosics and are much more thermally stable than the cellulosics. For this reason, ground battery casings are more capable of forming multi-particle bridges and maintaining them even at high temperatures.

\section{CONCLUSIONS}

1. In the static slot testing of conventional particulate lost circulation materials, the minimum useful maximum sealing pressure is 
taken to be of the order of $1000 \mathrm{psi}$.

2. Slot testing data exhibit significant scatter in the maximum sealing pressure which is not attributable to particle sorting or inconsistent mixing. Most scatter is attributed to the fluid mechanical plug formation mechanics.

3. Cellulosic materials are found to be useful in fracture widths equivalent to the diameter of the largest rigid particles in the LCM mixture. Back pressures less than 1000 psi are observed in cracks up to three times the maximum particle diameter. Beyond this no back pressures are observed. Hence, the maximum usefulness of typical LCM will be in sealing cracks which are less than 0.15 in wide.

4. Cellulosic materials are temperature sensitive. Of the materials tested cottonseed hulls rapidly degrade at $250^{\circ} \mathrm{F}$ while Ruf-Plug and Kwik-Seal are still stable at this temperature. At $400^{\circ} \mathrm{F}$ these latter materials decompose and are ineffective. Ground battery casings, on the other hand, are thermally stable at $400^{\circ} \mathrm{F}$.

5. Sealing in both API standard slots and modified 6 in long slots gave identical results, as plug formation occurs on the slot entrance.

6. Sealing in tapered slots was also investigated but the large scatter in the data prohibits conclusions about the location of the sea1.

\section{RECOMMENDATIONS}

1. Further study should be directed to the study of plug formation mechanics with primary emphasis directed toward higher strength particles necessary to support a high strength multi-particle bridge. This study should be conducted with the knowledge that bridging of a gap greater than three times the largest particle diameter appears highly unlikely.

2. Particle rugosities should be varied in an effort to improve multi-particle contact areas. 
3. Since typical loss zones probably involve cracks whose widths are greater than 0.15 in, bulk sealing techniques should be investigated which may allow sealing of larger fractures. 

1. Goodman, M. A., "Lost Circulation in Geothermal Wells: Survey and Evaluation of Industry Experience," SAND81-7129, July 1981 .

2. McDermott, J., Drilling Mud and Fluid Additives, Noyes Data Corporation, Park Ridge, NJ, 1973.

3. API Recommended Practice 13B, "Standard Procedure for Testing Drilling Fluid," American Petroleum Institute, washington, D.C., 1974, section 10.

4. Chenevert, M. E., "Fundamentals of Drilling," Short Course July 25-26, Sandia Laboratories, Albuquerque, NM, 1979.

5. I.A.D.C. Drilling Manual, International Association of Drilling Contractors, 1974.

6. Mickley, H. S., Sherwood, T. K., Reed, C. E., Applied Mathematics in Chemical Engineering, McGraw-Hill Book Co.. New York 1957.

7. Abrams, A., "Mud Design to Minimize Rock Impairment Due to Particle Invasion," J. Pet. Tech. 586-592 (1977).

8. Muecke, T. W., "Formation Fines and Factors Controlling Their Movement in Porous Media," SPE Paper No. 7007, 1978.

9. Perry R. H., Chilton, C. H., Kirkpatrick, S. D., Chemical Engineer's Handbook, 4th Ed., p. 23-62, McGraw-Hill Book Co., New York, 1963. 


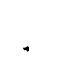

.

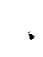




\section{APPENDIX}

\section{Analysis of Variance (ANOVA)}

The analysis of varlance of the data in Table 14 is performed by executing an F-test on this data. ${ }^{6}$ The F-test allows for comparisons of means to be made with relatively small sample sizes as long as a normal frequency distribution may be assumed. The F-test compares two estimates of the population variance. The first estimate is obtained from the difference between the sample means and the grand mean, $s_{p}{ }^{2}$, while the second estimate of the population variance is obtained from the error variance within the sampling groups, $\mathrm{s}_{e}{ }^{2}$. Thus, $\mathrm{F}$ is defined as

$$
F=\frac{s_{p}^{2}}{s_{e}^{2}}
$$

In equation ( $A 1$ ) the error variance, $\mathrm{s}_{e}{ }^{2}$, is given by

$$
s_{e}^{2}=\frac{\sum_{k=1}^{n_{i}}\left(x_{1 k}-\bar{x}_{1}\right)^{2}+\sum_{k=1}^{n_{2}}\left(x_{2 k}-\bar{x}_{2}\right)^{2}+\ldots}{n_{1}+n_{2}+\cdots-n_{i}}
$$

where $n_{i}$ is the number of sets and $x_{i k}$ are the $k$ data points in the $i$ th set. The variance of the population of means, $s^{2} p \cdot m$ is given by

$$
s_{p, m}^{2}=\frac{i_{i}^{n_{i}}\left(\bar{x}_{i}-\bar{x}_{p}\right)^{2}}{n_{i}-1}
$$

where $\bar{x}_{p}$ is the mean of the data from all sets. If $s^{2} p^{\prime} m$ is 
multiplied by $n_{0}$, the average number of data points in each set, then the second estimate of the population variance, $s^{2} p^{\prime}$ is

$$
s_{p}^{2}=n_{o} s^{2}, m
$$

If the samples have different sizes, then the average sample size, $n_{0}$, is given by

$$
n_{0}=\frac{1}{n_{i}-1}\left\{\sum_{i=1}^{n_{i}}\left(n_{k}\right)_{i}-\frac{\sum_{i=1}^{n_{i}}\left[\left(n_{k}\right)_{i}\right]^{2}}{\sum_{i=1}^{i}\left(n_{k}\right)_{i}}\right\}
$$

where $\left(n_{k}\right)_{i}$ is the number of measurements in the $i$ th set. Now $F$ may be computed in equation (A1) using equations (A2), (A3), (A4), and (A5). If $F$ is significantly greater than unity, then it is concluded that the variations of the means is significantly greater than the random fluctuations in the data, and that the difference in the means may be attributed to non-random factors. Conversely, a value of $F$ less than unity would indicate that random factors are larger than the assumed non-random factors and no positive statistical conclusions may be reached. 


\begin{tabular}{|c|c|}
\hline $\begin{array}{l}\text { DISTRIBUTION : } \\
\text { TID-4500-R66-UC-66c (507) }\end{array}$ & \\
\hline $\begin{array}{l}\text { Tom Anderson } \\
\text { Venture Innovations Inc. } \\
\text { P.O. Box } 35845 \\
\text { Houston, Texas } 77035\end{array}$ & $\begin{array}{l}\text { James W. Langford } \\
\text { Security Division } \\
\text { Dresser Industries, Inc. } \\
\text { P.0. Box } 24647 \\
\text { Dallas, Texas } 75224\end{array}$ \\
\hline $\begin{array}{l}\text { Ed Bingman } \\
\text { Shell Oil Company } \\
\text { Two Shell Plaza } \\
\text { P.0. Box } 2099 \\
\text { Houston, Texas } 77001\end{array}$ & $\begin{array}{l}\text { Harvey E. Mallory } \\
\text { P.O. Box } 54696 \\
\text { Tulsa, Oklahoma } 74155\end{array}$ \\
\hline $\begin{array}{l}\text { Larry Diamond } \\
\text { Dyna-Drill } \\
\text { P.O.Box C-19576 } \\
\text { Irvine, California } 92713\end{array}$ & $\begin{array}{l}\text { Gene Polk } \\
\text { NL Baroid } \\
6400 \text { Uptown Blvd. N.E.. } 365 \mathrm{~W} \\
\text { Albuquerque, New Mexico } 87110\end{array}$ \\
\hline $\begin{array}{l}\text { John E. Fontenot } \\
\text { NL Petroleum Services } \\
\text { P.O. Box } 60087 \\
\text { Houston, Texas } 77205\end{array}$ & $\begin{array}{l}\text { Del E. Pyle } \\
\text { Union Geothermal Division } \\
\text { Union Oil Co. of California } \\
\text { Union Oil Center } \\
\text { Los Angeles, California } 90017\end{array}$ \\
\hline $\begin{array}{l}\text { Dr. Melvin Friedman } \\
\text { Professor of Geology } \\
\text { Center for Tectonophysics } \\
\text { and Dept. of Geology } \\
\text { Texas A\&M University } \\
\text { College Station, Texas } 77843\end{array}$ & $\begin{array}{l}\text { John C. Rowley } \\
\text { Los Alamos National Labs } \\
\text { Mail Stop } 570 \\
\text { Los Alamos, New Mexico } 87545\end{array}$ \\
\hline $\begin{array}{l}\text { Tom Turner } \\
\text { Phillips Petroleum Company } \\
\text { Geothermal Operations } \\
655 \text { East } 4500 \text { South } \\
\text { Salt Lake City, Utah } 84107\end{array}$ & $\begin{array}{l}\text { William D. Rumbaugh } \\
\text { Research and Development } \\
\text { Otis } \\
\text { P.O. Box } 34380 \\
\text { Dallas, Texas } 75234\end{array}$ \\
\hline $\begin{array}{l}\text { Jim Kingsolver } \\
\text { Geothermal Operations } \\
\text { Smith Tool } \\
\text { P.O Box C-19511 } \\
\text { Irvine, California } 92713\end{array}$ & $\begin{array}{l}\text { Tom Warren } \\
\text { Amoco Production Company } \\
\text { Research Center } \\
\text { P.O. Box } 591 \\
\text { Tulsa, Oklahoma } 74102\end{array}$ \\
\hline
\end{tabular}


Distribution cont.

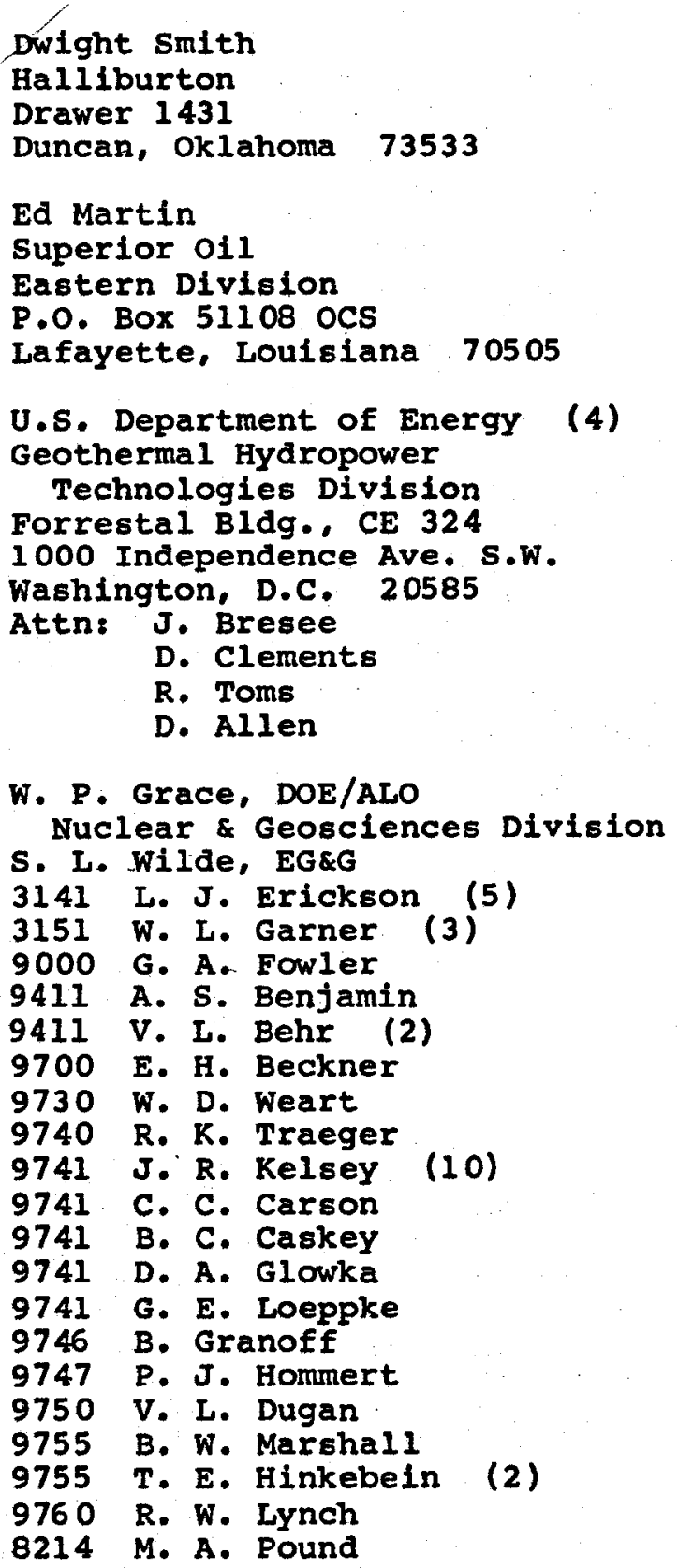

Ed Martin

Superior Oil

Eastern Division

. BOX 51108 OCS

U.S. Department of Energy

(4)

othermal Hyaropower

Technologies Division

1000 Independence Ave. S.W.

Washington, D.C. 20585

D. Clements

R. Toms

D. Allen

W. P. Grace, DOE/ALO

Nuclear \& Geosciences Division

S. L. Wilde, EG\&G

3141 L. J. Erickson

3151 W. L. Garner

(3)

G. A. Fowler

9411 A. S. Benjamin

9700 E. H. Beckner

9730 W. D. Weart

9740 R. K. Traeger

9741 J. R. Kelsey

9741 C. C. Carson

9741 B. C. Caskey

9741 D. A. Glowka

9741 G. E. Loeppke

B. Granoff

. Jommert

9755 B. W. Marshall

9755 T. E. Hinkebein (2)

8214 M. A. Pound

B. J. Livesay

Livesay and Carlson

129 Liverpool

Cardiff, California 92007 